\title{
RURAL TOURISM AS PROMOTER OF RURAL DEVELOPMENT - PROSPECTS AND LIMITATIONS: CASE STUDY FINDINGS FROM A PILOT PROJECTPROMOTING VILLAGE TOURISM
}

\author{
Stefan Neumeier, Kim Pollermann ${ }^{1}$
}

Received 2 April 2014; Accepted 26 September 2014

\begin{abstract}
The article questions where and how rural tourism (with special focus on small scale village tourism) that is often focused on in rural development initiatives can contribute to rural development in the light of the OECD's 'new rural paradigm'. For this purpose theoretical findings from research about tourism and factors of success of rural development processes are combined and reflected against findings of empirical research conducted in five eastern German rural regions. It is shown that although tourism might, in the majority of rural regions, induce only small economic impacts - which indicate failure as a factor for regional development - it can cause important non-economic implications. Thus, even in regions not suitable for tourism, tourism can function as a vehicle for rural development. Thereby it is important to develop a suitable strategy and consider the specific regional situation and potentials of success.
\end{abstract}

Key words: tourism, rural development, pilot project, funding, Germany

Zusammenfassung: Der Artikel untersucht wo und wie ländlicher Tourismus (mit Fokus auf Dorftourismus), der häufig in ländlichen Entwicklungsinitiativen im Rahmen des 'new rural paradigm' der OECD als eine vielversprechende Möglichkeit angesehen wird Entwicklung zu initiieren dem Ziel auch gerecht werden kann. Dazu werden theoretische Erkenntnisse der Tourismusforschung mit Erkenntnissen zu Erfolgsfaktoren ländlicher Entwicklungsprozesse betrachtet und mit empirischen Forschungsergebnissen aus fünf ostdeutschen ländlichen Regionen widergespiegelt. Dabei zeigt sich, dass, obwohl Tourismus in der Mehrheit der ländlichen Regionen nur geringe ökonomische Erfolge hervorbringt - was zunächst dafür spricht, dass Tourismus kein geeignetes Mittel zur Entwicklung ländlicher Regionen ist Tourismus auch wichtige, außerökonomische Entwicklungseffekte initiieren kann. Als Ergebnis last sich daher festhalten, dass Tourismus auch in Regionen, die sich eigentlich nicht für eine touristische Inwertsetzung eignen als Katalysator für Entwicklungsprozesse fungieren kann. Dazu ist jedoch eine entsprechende an die spezifischen regionalen Gegebenheiten angepasste Strategie unter Berücksichtigung der Erfolgsfaktoren ländlicher Entwicklungsprozesse notwendig.

\footnotetext{
${ }^{1}$ Dr. Stefan Neumeier, Dr. Kim Pollermann, Institute for Rural Studies, The Thünen Institute, German Federal Institute for Rural Areas, Forestry and Fisheries, Bundesallee 50, 38116 Braunschweig, Germany, e-mails: stefan.neumeier@ti.bund.de, kim.pollermann@ti.bund.de.
} 


\section{Introduction}

The article critically questions where and how as well as where not and why rural tourism (in the form of small scale tourism) can contribute to rural development. Therefore we use empirical results from a pilot project for village tourism. Object of investigation is rural tourism in European countries. As such initiatives are supported by the European Union political strategies regarding rural development since the end of the 1980s (Figueiredo and Raschi, 2013), there is a long history of rural tourism as a measure to maintain rural areas.

Thereby especially small scale rural tourism is often seen as one promising solution to support or initiate regional development in structurally weak rural areas - especially on the part of politicians and administrations responsible for rural development (McAreavey and McDonagh, 2010; Matarrita-Casante, 2010; Saxena and Ilbery, 2008; Terluin, 2003; Dong et al., 2013).

So, tourism is also a key target sector in the so called 'new rural paradigm' from the OECD, whose main characteristics are a focusing on places instead of on sectors and an emphasis on investment rather than subsidies (OECD, 2006; Ward and Brown, 2009). Thus, the "new rural paradigm' promotes integrated rural development by accounting for co-ordination across sectors, across levels of government and between public and private actors (OECD, 2006).

In this regard it is supposed that tourism can, on the one hand, contribute to the creation of new job opportunities outside of agriculture and also strengthen the often declining small trade companies; and on the other hand trigger positive economic impulses in industries related up- and downstream to tourism. But reality is often not that simple. And in addition it is difficult to measure regional impacts of tourism (Madsen and Zhang 2010).

Nevertheless, although sometimes only minor economic effects can be triggered by efforts to establish rural tourism, other effects like the enhancement of regional identity or socio-political change can be registered instead (so in ideal cases, tourism indirectly helps to empower local communities and build capacity which, in turn, improves the livelihoods of the affected communities (Nyaupane and Poudel, 2011), suggesting that there are different ways rural tourism can contribute to rural development (Belletti et al., 2013, p. 94; Brandth and Haugen, 2011 lorio and Corsale, 2010). Nevertheless tourism does not only induce positive effects but might also have negative impacts on local development constraining its suitability as rural development measure (Wilson et al., 2001, p. 132; Belletti 2013, p. 94). For example, tourism activities may contribute to an increase in conflicts among the local population, tourists and tourism operators (Figueiredo and Raschi, 2013, p. 9).

The limitations of regional economic development through tourism are well acknowledged in the existing literature (see for example: Neumeier and Pollermann, 2011, Figueiredo and Raschi, 2013; Gascón, 2013).

This article is a further, more detailed step to find a suitable way to deal with the constraints and opportunities in practice. Against this background the article focuses on the questions of where and how tourism can contribute to rural development and in which way this can be supported through participatory planning at the local level and via funding programs which contributes to realistically asses its possible constraints as well as opportunities as means of rural development. The article is divided into three sections:

Following this introduction, Section Two focuses on theoretical aspects by considering what rural tourism is and how it can contribute to rural development. This section also presents knowledge from empirical research found in the literature.

Section Three takes the pilot project "Income maintenance through village tourism" as an example and discusses experiences within rural development from a participative tourism development approach applied to five eastern German peripheral rural areas at the local level.

In the concluding section the findings about the role of tourism as a factor of rural development are summarized. Thereby the findings are reflected against scientific 
knowledge on factors of success of rural development processes in order to derive recommendations for the future shaping of projects and programs promoting rural tourism within rural development.

\section{Theoretical background: Definitions and assumptions}

\subsection{Tourism versus rural tourism}

"There is little consensus on the definition for rural tourism. Researchers from different countries have developed their own definitions based on their unique experiences or contexts" (Nair et al. 2014). So when talking about rural tourism, it is important to define the term first.

This is not easy because the definition of tourism itself is already quite problematic and different views exist as to its nature (cp. Johnston et al., 2000; Darbelly and Stock, 2011). In general, tourism is defined as all activities of persons travelling and staying in places outside their place of work, residence or provision, for longer terms - but for not more than one consecutive year for leisure, business and other purposes not related to the exercise of an activity remunerated from within the place visited (cp. OECD, 2002; Leser et al,. 1992). Commuting and shopping, as well as local recreation not connected with at least one overnight stay are, according to the general tourism definition, explicitly not part of tourism (cp. Leser et al., 1992).

To clearly define rural tourism is also difficult because rural tourism is, similar to the rural areas multi-faceted, rarely either static, self-contained, or free from urban influences (Lane, 1994, p. 910). Therefore, the nature of rural tourism is in many aspects different from tourism in general. As possible spectrums for defining rural tourism, rural tourism is, on the one hand, seen as all touristic activities taking place in rural areas, or, on the other hand, restricted to very specific categories or forms of tourism, as for example farm tourism (Oppermann, 1996, p. 87) or agritourism (Flannigan et al. 2014). Sometimes wilderness tourism or temporary stays in second homes in rural areas are included, sometimes not (cp. Oppermann, 1996, p. 87).

To give a concise general definition considering the broad spectrum of possible forms rural tourism might have, Lane (1994) defines rural tourism as tourism taking place in rural areas, which are characterized by low population densities and open spaces; small-scale settlements with generally less than 10,000 inhabitants and land use mainly dominated by farming, forestry and natural areas (cp. Lane, 1994, p. 14).

But similar to rurality (with its "Plurality of Rurality" (Lukić 2013)), rural tourism should be seen as a continuum of different forms of tourism subject to the region/location where it is taking place (Lane, 1994, p. 15-16). That is, "the demand for rural tourism is related directly to the particular characteristics of rural areas" (Sharpley and Roberts, 2004, p. 120). So according to Lane (1994) rural areas close to urban areas are most likely to display some urban trends, whereas peripheral rural areas while attracting lower levels of tourists may offer more opportunities for more rural-specific tourism activities (cp. Lane, 1994, p. 15; Sharpley and Roberts, 2004, p. 119) (see Figure 1). For example, farm tourism is typically rural, while cultural tourism is often a more urban form of tourism. In contrast, wellness tourism is in between.

As according to our opinion the understanding of rural tourism as expressed by Lane (1994) takes into account the different facets of rural tourism quite well, that can be actually found in the quite different non urban areas commonly addressed as rural, when talking about rural tourism in the remainder of the article we adopt Lane's (1994) definition but contrasting the definition of tourism in general widen its scope explicitly to local recreation/day tourism, which might - as we will see later - have a certain importance especially in rural areas in the urban hinterland. 


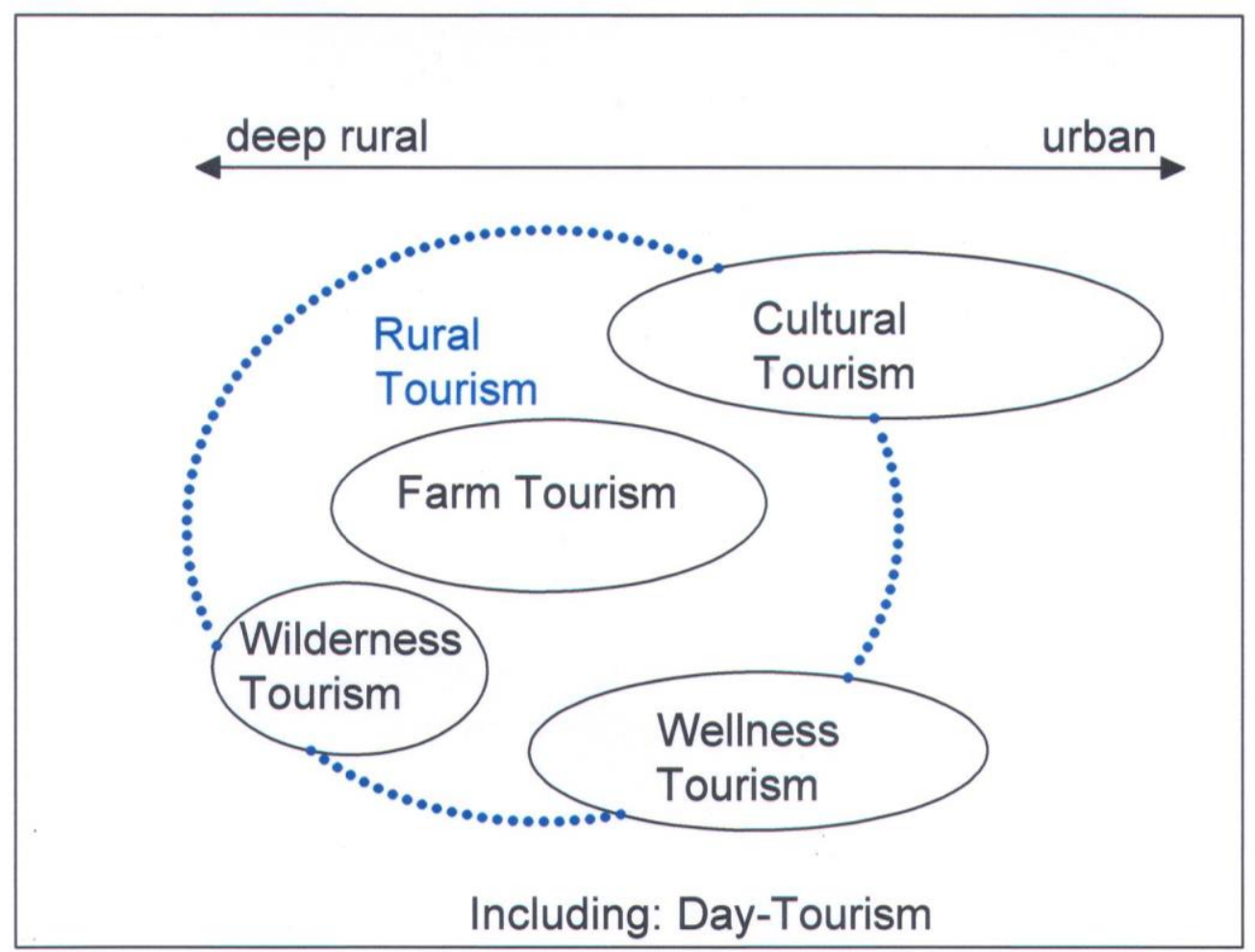

Fig 1. Conceptual model rural tourism as a continuum.

So, when talking about rural tourism we mean tourism as well as recreation/day tourism taking place in rural areas which are characterized by low population densities and open spaces; small-scale settlements with generally less than 10,000 inhabitants and land use mainly dominated by farming, forestry and natural areas. Thereby rural tourism strongly builds on the specific rural world's features and comprises a continuum of different forms of tourism subject to the region/location where it is taking place. In more detail, in the case studies we will discuss, we especially refer to small scale rural village tourism taking place in municipalities with less than 10,000 inhabitants (in the majority of the five cases less than 1,000) with no existing large regional or even supra-regional tourism enterprises which are quite typical for areas addressed by rural development initiatives in light of the OECD's 'new rural paradigm'.

\subsection{Tourism as a factor of regional development}

Tourism as a whole is thought to be one of world's largest industries (Wallace and Russel, 2004; Saarinen, 2006) with a still continuing economic growth (McAreavey and McDonagh, 2010). For example in 2005, 440 million tourist arrivals were recorded in the European states, accounting for $10 \%$ of the European Gross Domestic Product and 20 million jobs (Tourism Sustainability Group, 2007, p. 2). Rural tourism also makes a significant contribution to the rural economy and to the wider tourism industry. For example there are estimations that in England rural tourism creates 380,000 jobs (Haven-Tag and Jones 2012). Because of figures like these, tourism experts assume that tourism has a great potential to contribute to regional economic growth (cp. Wilson et al., 2001; Jensen-Butler et al., 2007; Deller, 2009). The reason is that money spent by tourists flows in industries up- and downstream to tourism and thus activates regional economic growth - but only if the operators of tourist facilities obtain their provisions and needs from local markets. If not, which is often the case with, for example, national or international hotel chains, the benefit for the region will be only marginal (cp. Jensen-Butler et al,. 2007; Belletti et al. 2013). In economic terms the logic behind regional development via tourism can be explained with different models (shown in detail in Madsen and Zhang, 2010). Another reason that tourism is thought to be a promising option to contribute to regional economic growth is that sometimes in regions where pre-conditions for other economic development are quite disadvantageous, quite favourable pre-conditions for the development of tourism might exist. Thus, especially in rural regions which have undergone economic 
restructuring with a declining role of agriculture, great hopes are pinned on tourism as a central factor of economic development and income opportunities for the rural population (JensenButler et al., 2007; Cawley and Gillmor, 2008; Deller, 2009; Brandth and Haugen, 2011). Following these arguments rural tourism development often starts as an initiative of a local government (Komppula 2014, p. 364).

But already Dwyer et al. (2004, p. 307) claimed "The importance of tourism to economies is now well recognised. As a result, when tourism changes or policy shifts are being considered, there is an interest in determining what impact on the economy they might have. However, the approach to economic evaluation typically undertaken in the tourism context, "is both incomplete and misleading". So, although the potentials of tourism as factor of regional development are well acknowledged it is up to now still often difficult to concretely measure the economic impact of rural tourism in detail (Madsen and Zhang 2010).

Furthermore, considering tourism as factor of development we should be aware that the success of tourism is strongly depending on regional conditions, that tourism is subject to seasonal changes and susceptible to risk which might in some cases relativize its potentials considerably. Altogether high destination competitiveness might contribute to attracting more visitors to a destination, but this does not automatically mean that local people benefit from tourism development (Webster, Ivanow 2014). To strengthen the benefit option for locals there are approaches like a community based tourism or a local leadership, which fits to small scale rural tourism (Haven-Tag, Jones 2012; Blackstock 2005).

So, to fully understand tourism's economical transitions the interplay of processes at least at following three different levels are relevant: micro- (local), meso- (regional) and macro(European) level (Randelli et al., 2014).

\subsection{Requirements for touristic attractiveness}

In order to successfully develop an economically viable tourism, it is necessary to develop an attractive, competitive touristic profile. That means a tourism destination must offer a variety of products and services (Haugland et al., 2011; Dong et al., 2013), which are constantly being adapted to changes in demand by the different regional stakeholders (McAreavey and McDonagh, 2010; Belletti et al., 2013). Another important aspect is that the touristic-profile is developed from within the region itself so that it will be accepted to the same degree by locals as by tourists. Regions that cannot be competitive, and where the touristic infra- and suprastructure, as well as the attitude towards the tourists, fail to meet the standards expected by the tourists will not profit from tourism in the long run. Furthermore an offensive marketing and advertising campaign for the region is indispensable (cp. Wilson et al., 2001). Connections to the wider region and other destinations are an advantage as these poses opportunities to exchange experiences (Fink and Plankl, 1998, p. 105-106; Haugland et al., 2011).

Besides prerequisites attributed to some kind of attractions as well as natural and cultural landscapes within a region, the amount and quality of the service infrastructure and touristic supra-structure, as well as the service-ethos of the local population are important factors for a successful tourism development (cp. Wilson et al., 2001).

Altogether, focusing on a tourism that may induce noteworthy economic effects, the touristic attractiveness can be positioned within the following seven building-blocks of a holiday (Romeiß-Stracke, 1989, p. 12): "Accommodation", "Food, Beverage", "Service" (including information), "Infrastructure", "Character of the village or region", "Natural prerequisites", "Traffic, accessibility". Thereby it has to be mentioned that although this seven building-blocks represent only a quite simplified model, they constitute a suitable basis for the further discussions in this article (for a more detailed literature overview about "Tourism destination: development and competitiveness" see Lukić 2013).

The interplay of these and additional building-blocks (such as promotion and booking possibilities and marketing as a super-ordinate building-block) has proven to be important for success or failure. The development of these building-blocks is formed through complex networks of actors and strongly contributes to the image formation of a successful tourist 
destination (Haugland et al., 2011; Figueiredo and Raschi 2013; Volgger and Pechlaner 2014) and a high competiveness of a rural tourism destination (Komppula 2014).

For a credible rural tourism product, most tourists also expect some local authenticity (Cawley and Gillmore, 2008; Brandth and Haugen 2011; Flannigan et al. 2014). For example in connection with local food experiences (Sidali et al. 2013). For more detailed research about destination attractiveness see: van der Borg (2008); Kamata et al. (2010); Haugland et al. (2011) as well as Dong et al. (2013) who recently presented a study about travel motivations and characteristics of tourists visiting a rural destination in the United States. But it is not sufficient only to take into account the local attractive features, rather it is important to also look on the demand. So, similar to tourism in general, for a successful rural tourism a demandanalysis (including target group analysis) and target-oriented marketing strategies are a prerequisite which is one of the reasons that "marketing" represents one of the super-ordinate building-blocks of a destination.

\subsection{Constraints and opportunities for rural development via rural tourism}

Against the background of the loss of jobs in agriculture and industry, caused by structural change, tourism can locally and individually create jobs and other possibilities to earn a living. But not as broadly and of such macroeconomic importance that it will be able to replace the productive sector or compensate its decline (cp. Benthien, 1995; Figueiredo and Raschi 2013). In a similar way Terluin (2003) summarises her findings about differences in economic development in rural regions in western Europe: "The pattern of employment growth shows that tourism, which is often one of the main pillars in rural development programmes, is not the only potential source of rural employment growth, but one amongst many other branches" (Terluin, 2003, p. 338). McAreavey and McDonagh (2010, p. 13) mention that a "paradox in this debate is seeming desire to replace one vulnerable activity (agriculture) with another (tourism)."

As seen, the considerations about tourism and regional development clearly distinguish between regions suitable for establishing an economically successful, or respectively intensive, rural tourism and regions more suited for extensive forms of tourism with only minor prospective value added from tourism.

But the majority of rural areas do not have enough cultural, natural or other attractions suitable for developing outstanding unique selling propositions, clearly distinguishing the region from other regions creating possibilities for the development of an economically successful, or respectively intensive, rural tourism. In addition, there is a hard competition among tourism regions within a country as well as with international destinations. In this regard, for the majority of peripheral rural areas, disadvantageous preconditions can be registered for infrastructure and accessibility so that the critical mass of guests important for a successful tourism cannot be reached (Deller 2009; Benthien 1995).

Another important aspect to consider, mentioned by Pike et al. (2007) is the question, of who in the region profits from tourism (see also Belletti et al., 2013, p. 94). A study in Romania shows, for example, that creating a tourism enterprise can create a suitable additional income and fits well to the livelihood strategies of the families of the owners of tourism enterprises. But the study also clarifies that the capital that is required to develop a property for tourists excludes the poor rural residents from participating (lorio and Corsale, 2010). In addition new leisure and recreation opportunities created might not be a benefit for all of the local residents as some may not be able to afford the services provided themselves. Furthermore in general, aside from the management, tourism offers often only low paid inferior job opportunities that are sometimes even only seasonal (Deller, 2009).

Taking this considerations in account it can be concluded, that all in all, except for few exceptions with outstanding unique selling propositions (or chances to develop such), for most rural regions, and especially peripheral rural regions, the development of extensive forms of tourism with only minor economic effects seem to be realistic. Therefore it is quite surprising that within rural development, tourism seems to be again used as some kind of promising universal remedy - especially on the part of some politicians as well as administrations especially for structurally weak rural regions (Figueiredo and Raschi, 2013; Dong et al., 2013). 
So, if the potential economic effects of tourism are likely to be marginal in the majority of rural regions, this poses the question of what other effects tourism might induce in these regions justifying the implementation of tourism projects within the scope of rural development?

To answer this question it is important to consider the success or failure of tourism as a factor of rural development not only in economic terms as it is unfortunately quite-short sighted done too often.

Instead, two possible forms of tourism and tourism development should be distinguished. One that is in line with the mainstream economic development paradigm focusing on hedonistic recreational activity and one that focuses more on socio-political change (cp. Stronza, 2001, p. 264; Nyaupane and Poudel 2011).

This observation is, according to our understanding, quite in line with Lane's (1994) perception of rural tourism as a continuum, whereas for different regions, different forms of tourism seem to be suitable, leading to different forms of development opportunities (economic, social, cultural) or negative effects (Belletti et al., 2013). Simultaneously tourism, as a factor of rural development, has to be analysed in a quite differentiated manner, and its success should not be measured only on its direct economic impacts.

It is also especially interesting whether tourism contributes to a general improvement of a collaboration of different actors, because such implications are generally an integral part of recommendations for economic development in rural areas: "Strengthen the cooperation of local actors and the cooperation of actors inside and outside the region. This cooperation facilitates the creation and maintenance of networks and public/private partnerships and may result in local synergy [...]. In addition, a cultural-territorial identity may also serve as a main catalyst in raising local consciousness towards cooperation," (Terluin 2003, p. 342).

Overall, beyond economic aspects, a touristic development influences social, cultural and ecological matters, which should also be taken into account, as these might induce positive as well as negative impacts important for the region and the overall regional development. (Cawley and Gillmor, 2008; McAreavey and McDonagh, 2010; Belletti et al. 2013).

Given the recognition that focusing on economic aspects alone does not adequately capture the dynamics of economic performance of rural areas, aspects of social-cultural changes should be taken into account as an additional explanatory factor, too. The reason is that social relations and networks are quite important for economic interactions in regional development especially for neo-endogenous approaches (Agarwal et al., 2009; Dax et al., 2013). Promotion of issues such as the empowerment of local people should be part of the objective for integrated rural tourism (Cawley and Gillmore, 2008; Nyaupane and Poudel, 2010). A sustainable approach to tourism avoids an unbalanced approach to economic growth by using tourism as a tool for broader economic progress, actively seeking alternatives to tourism (cp. Lane, 1994, p. 19).

\subsection{Support for touristic development via planning and funding}

The constraints and opportunities raise questions about the management and related policy approaches of these issues. Especially how planning and/or funding (from European or national sources) can really contribute to a durable successful development.

The development of a destination is achieved by different actors in the rural area, and the success of individual actors, as well as the success of the entire destination, is dependent on efficient coordination (Haugland et al., 2011). Thereby touristic developments have different causes, only some of them can be influenced via planning and there are also restrictions for steering the development. Thus, Baggio et al. (2010, p. 55) describe destination development as a task of "finding the way to direct a complex system which, almost by definition, is quite unmanageable". This, and the importance of the different building-blocks named earlier, make clear that there should be an integrated and participatory planning approach.

It is a key issue for the development of rural tourism to involve all stakeholders on a regional level, and it is especially important that there are organizational structures, which permit continuous progress (Pollermann, 2004; Cawley and Gillmor, 2008). In addition the importance 
of individual entrepreneurs is highlighted by Komppula (2014). These organizational structures have to connect different actors with diverging interests: From a thematic point of view one can for example differentiate actors from agriculture, tourism, nature conservation or local trade and handicraft. Another distinguishing factor to be taken into account is the sector to which the actors belong: the state, the private sphere or the civil society, also in sense of a Governance-arrangement (Pollermann, 2013; Volgger and Pechlaner, 2014). One of the main principles for participatory planning is that insiders have expertise that should contribute to the work (Korf, 2007, p. 261).

An organizational structure should provide a framework within which strategic decisions (in relation to the objectives - here tourism), organizational decisions (regarding the use of resources) and operational decisions (regarding the delivery of the outputs) are made (Jobin, 2008 , p. 441). Altogether, the collaboration of different types of actors needs more time, but it enables better solutions and reciprocal learning processes. This is especially important for the aspect of socio-political change (s. chapter 2.4).

Continuous work is necessary to support the development of a tourist destination. In order to be able to properly coordinate this development, a planning strategy that builds up on potentials of success is needed. Such potentials not only influence the results of planning processes, but they are changeable themselves. In order to combine the potentials which determine the success of planning for rural tourism development, the following six main strategic success-potentials could be identified based on empirical research and a broad review of German literature about success factors of participatory planning, which was also verified by expert interviews in Germany, Austria and Switzerland (derived by Pollermann, 2004; updated by Neumeier et al., 2011): "Quality of professional concept", "Organizational structure", "Commitment of the participants", "Abilities of the participants", "Level of acceptance and cooperation", "Access to material resources".

For the development of the planning-strategy, the initial conditions specific to the region need to be determined to adapt the strategy to its specific conditions ("strategy-fit") at an early stage. Of course the strategy has to fit the demands of tourists, so the strategy-fit can be supported by a market analysis (s. chapter 2.4).

As already mentioned, funding of tourist activities is a common approach in European rural development programs (Belletti et al. 2013; Randelli et al., 2014; Pollermann et al., 2013).

Due to external funding it is important to strengthen the activities of local actors in general and use the most suitable endogenous potentials (Terluin, 2003).

It is more problematic for policy to influence economic performance by overcoming problems associated with poor accessibility and peripherality. In contrast, improving rural economic performance by raising skills is more amendable to policy intervention (Agarval et al,. 2009, p. 318).

Besides it should always be questioned to what extent lasting self-contained processes develop, projects and measures should be stable after the expiration of external support.

\section{Practical experiences: A pilot project in Eastern Germany}

\subsection{Approach and aims of the pilot project}

In order to test the opportunities of rural tourism for peripheral rural regions in eastern Germany, in 1993 - just three years after the German reunification in 1990 - the German Ministry of Food, Agriculture and Forestry initiated the model-project "Income maintenance through village tourism." The main objective of the project was to develop exemplary rural tourism in rural areas typical for the eastern federal states of Germany that do not have any touristic experience and that are not exceptionally suited for a tourist valorisation in order to achieve an income maintenance through village tourism. To choose rural tourism as a vehicle for an economic development approach against the background of the situation of Eastern Germany just after the reunification in 1990 has been quite reasonable because: In rural policy "rural tourism has long been considered as a means of achieving economic and 
social development and regeneration. More specifically, it has been widely promoted as an effective source of income and employment, particularly in peripheral rural areas where traditional agrarian industries have declined" (Sharpley, 2002). This, together with the fact, that in structurally weak areas such as the project regions other possibilities for economic diversification outside agriculture seemed to be difficult to develop (also see chapter 2.2) have been the decisive factors to focus on rural village tourism as means of rural development. Thereby only regions that may have an exemplary function, that means villages that are ideal-typical for rural regions within the federal state, came under consideration (so this is why it was called a model-project: to use the project as a model to test the suitability of the approach as possible measure of rural development for other similar regions). Figure 2 shows the five municipalities which were chosen to participate. Thereby a neo-endogenous approach (cp. Ray, 2006) ${ }^{1}$ to tourist development was pursued. The selected villages were not supported by extra funding, but the local actors were professionally advised as to how they can apply for funding. Thereby following objectives have been pursued (see Neumeier, Pollermann, Jäger 2011):

- Aims related to contents: Increasing the tourist attractiveness of the areas, generating income via tourism, economic stabilization.

- Aims related to methods: Activating public participation, triggering self-contained activities / utilizing funding programs, initiating and ensuring long term commitment for the own local area.

Long term impacts of participative planning processes that aim to activate citizens can only be assessed after a longer time span. But concomitant research often concentrates only on the project period or a short time after. In this regard the model-project is an outstanding exception, as the success, as well as long-term development was evaluated over a period of 15 years within two phases of research 1995-1998 (Fink and Plankl, 1998), 2005-2009 (Neumeier et al., 2011).

\subsection{Characteristics of the model villages}

Glaisin: Glaisinhas 354 inhabitantsand can only be reached via minor country roads. Public transport is quite poor. The overall appearance of the locality is, with its well-preserved halftimbered unplastered houses, quite appealing. The village centre is dominated by the "Forsthof ensemble" (a country inn with adjacent culture-barn bakehouse and spiral herb garden) renovated subsequent to the pilot project. There are no outstanding tourist attractions. The next tourist attraction is the baroque palace of Ludwigslust (eight kilometres away). 


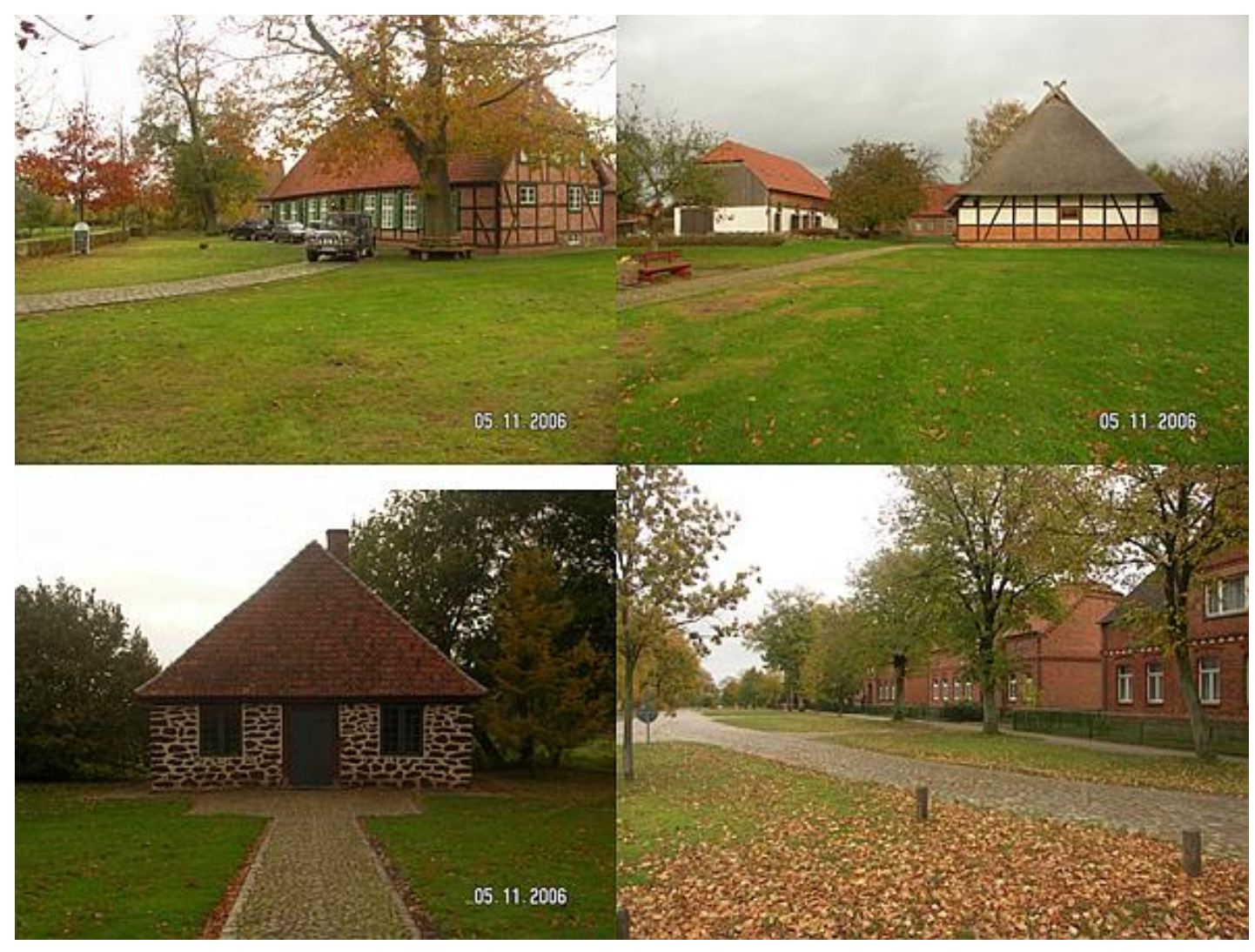

Fig 2. Impressions from Glaisin.

Schlieben: The sleepy little town of Schlieben is located in the Elbe-Elster County and has 5,881 inhabitants. The location is surrounded by spruce forests typical for Brandenburg. One peculiarity of Schlieben is that it is one of the northernmost wine-growing regions in Germany. Apart from the historical wine cellars, the area has no outstanding tourist attractions.

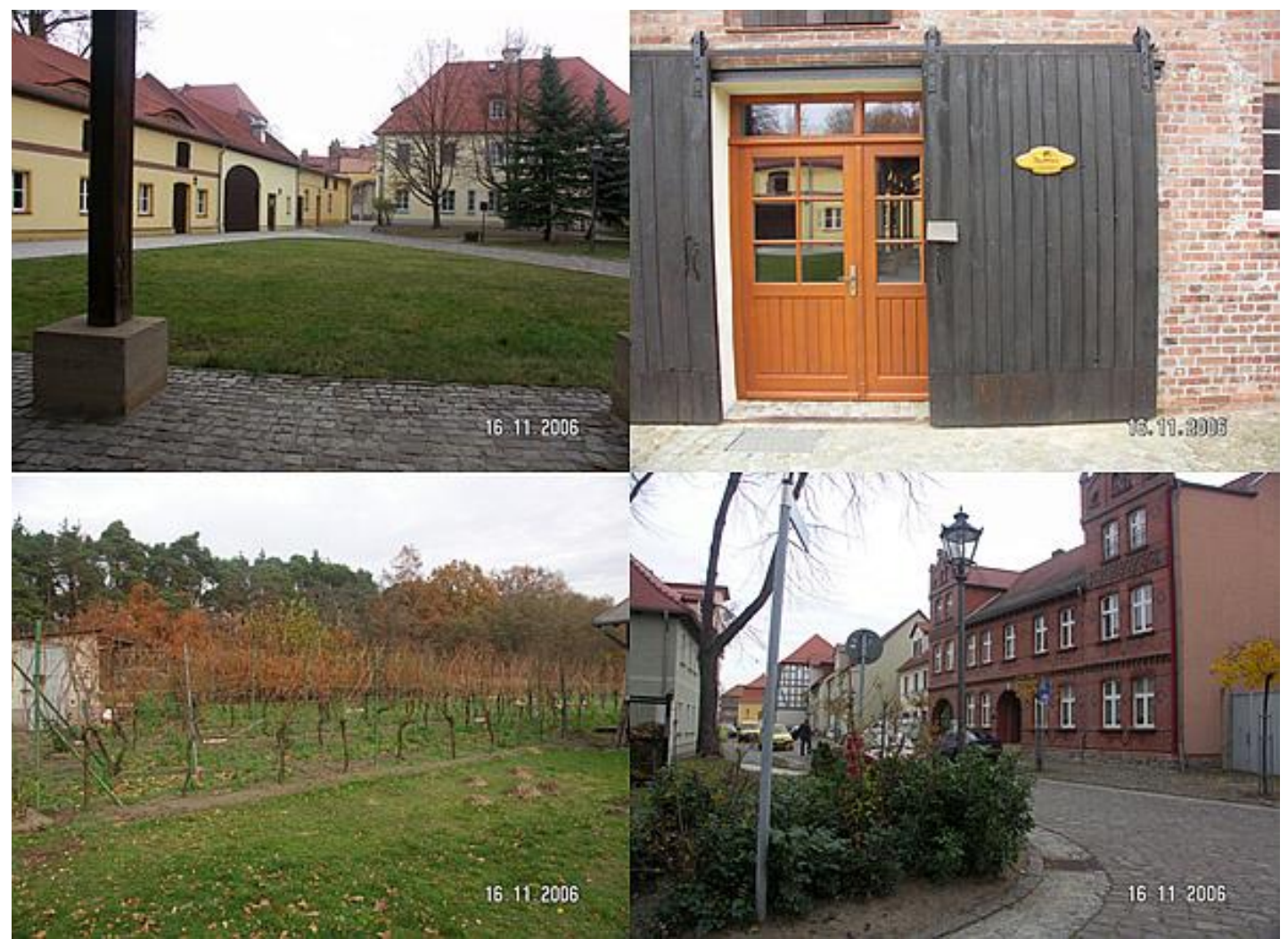

Fig 3. Impressions from Schlieben. 
Kläden: Kläden is situated in the cultural landscape of the Altmark. It has about 9,877 inhabitants. The impacts of the demographic changes are quite obvious. High vacancy rates and an aging population are characteristic. The area itself does not have any outstanding tourist attractiveness, it is difficult to reach by public transportation and has only very basic gastronomic services.

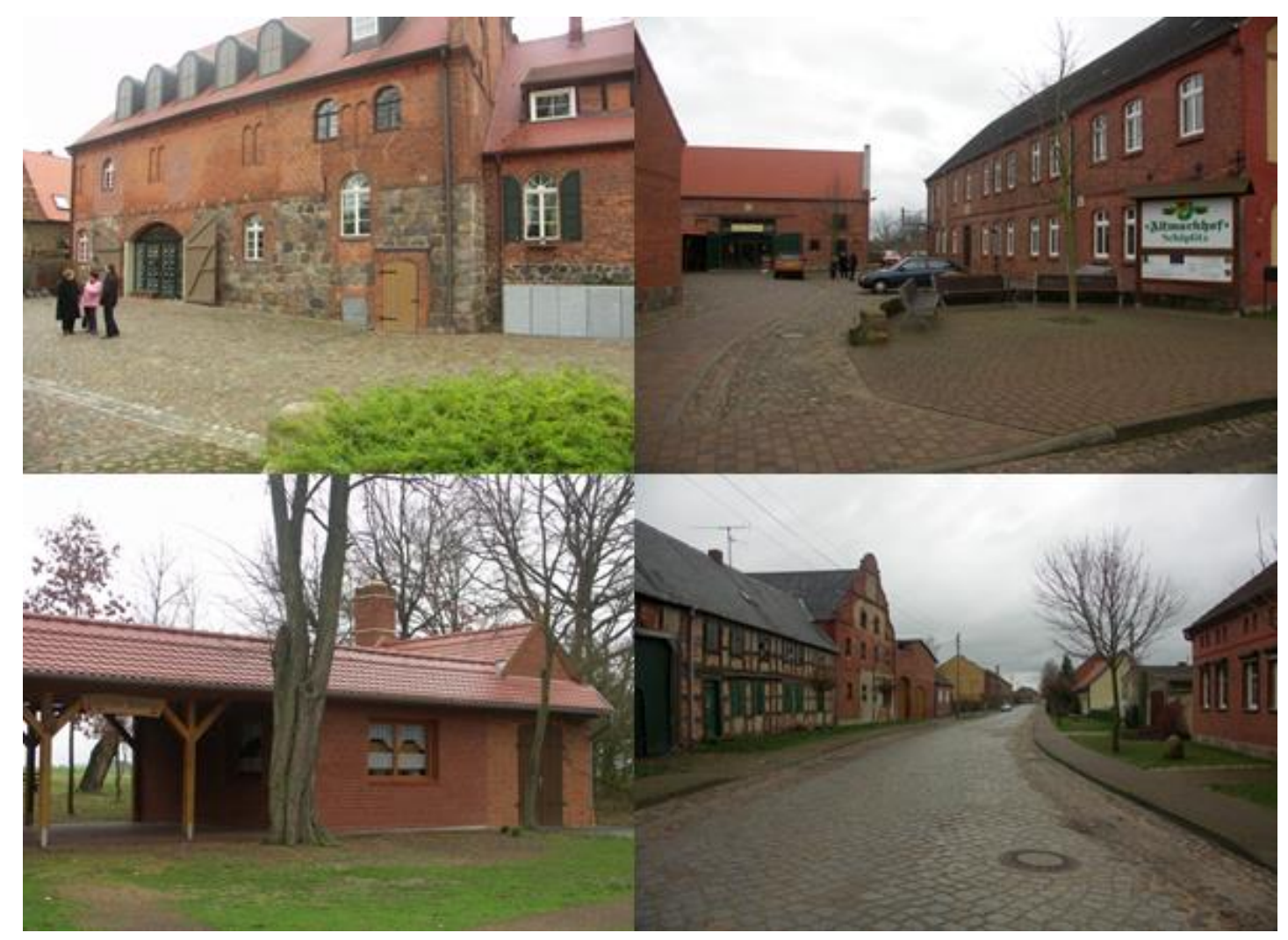

Fig 4. Impressions of Kläden.

Lawalde: Lawalde is situated in the Oberlausitz. The community has about 850 inhabitants. Characteristic for the region are a special kind of buildings with timber framing. This peculiarity is not well-marketed in Lawalde and the whole character of the village (deterioration of the buildings, grey as predominant house paint) reminds earlier times in the German Democratic Republic (belonging to the eastern Bloc until the reunification; of Germany in 1990). As tourist attractions Lawalde advertises its billiard, table tennis and mini-golf facilities as well as a private collection of cacti.

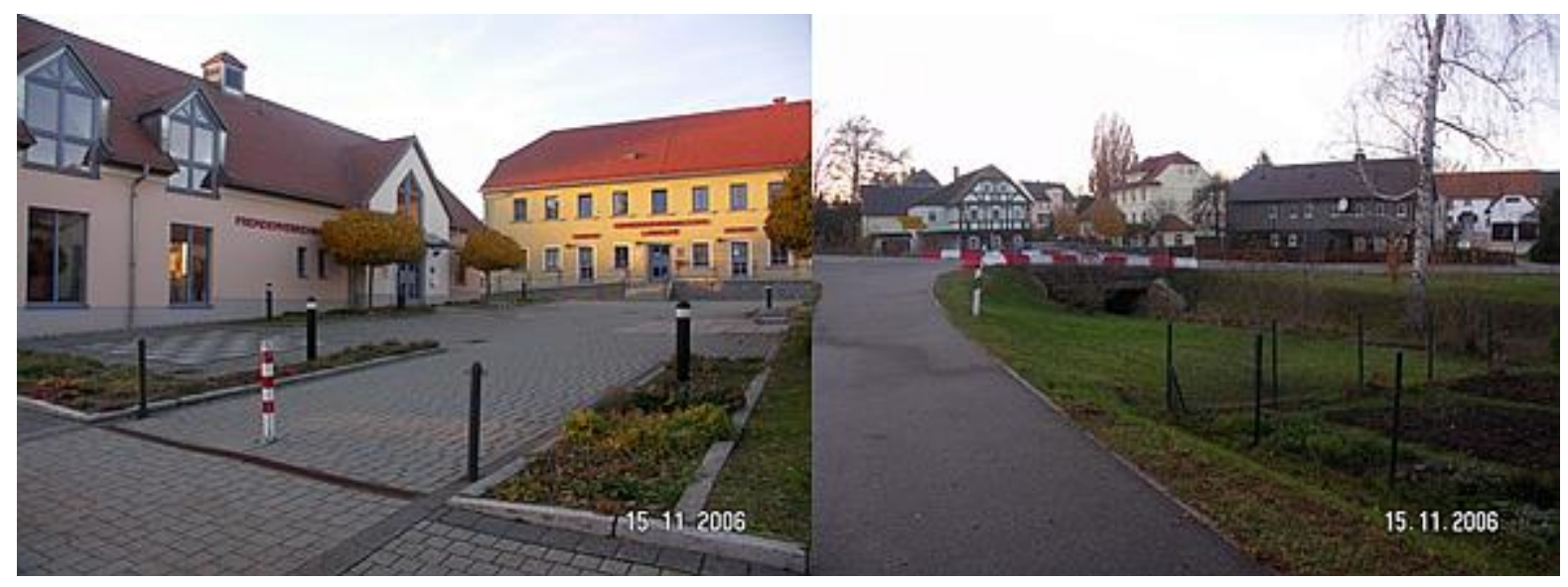

Fig 5. Impressions of Lawalde. 
Brunnhartshausen: Brunnhartshausen is located in the mountainous area of the Rhön, an attractive tourist region. The village has about 400 inhabitants. All in all Brunnhartshausen itself does not have any outstanding peculiarities or unique selling points. Because of the German-Democratic-Republic-history (next to the border) the tourism in the eastern part of the Rhön is in general less developed than in the western part of the Rhön.

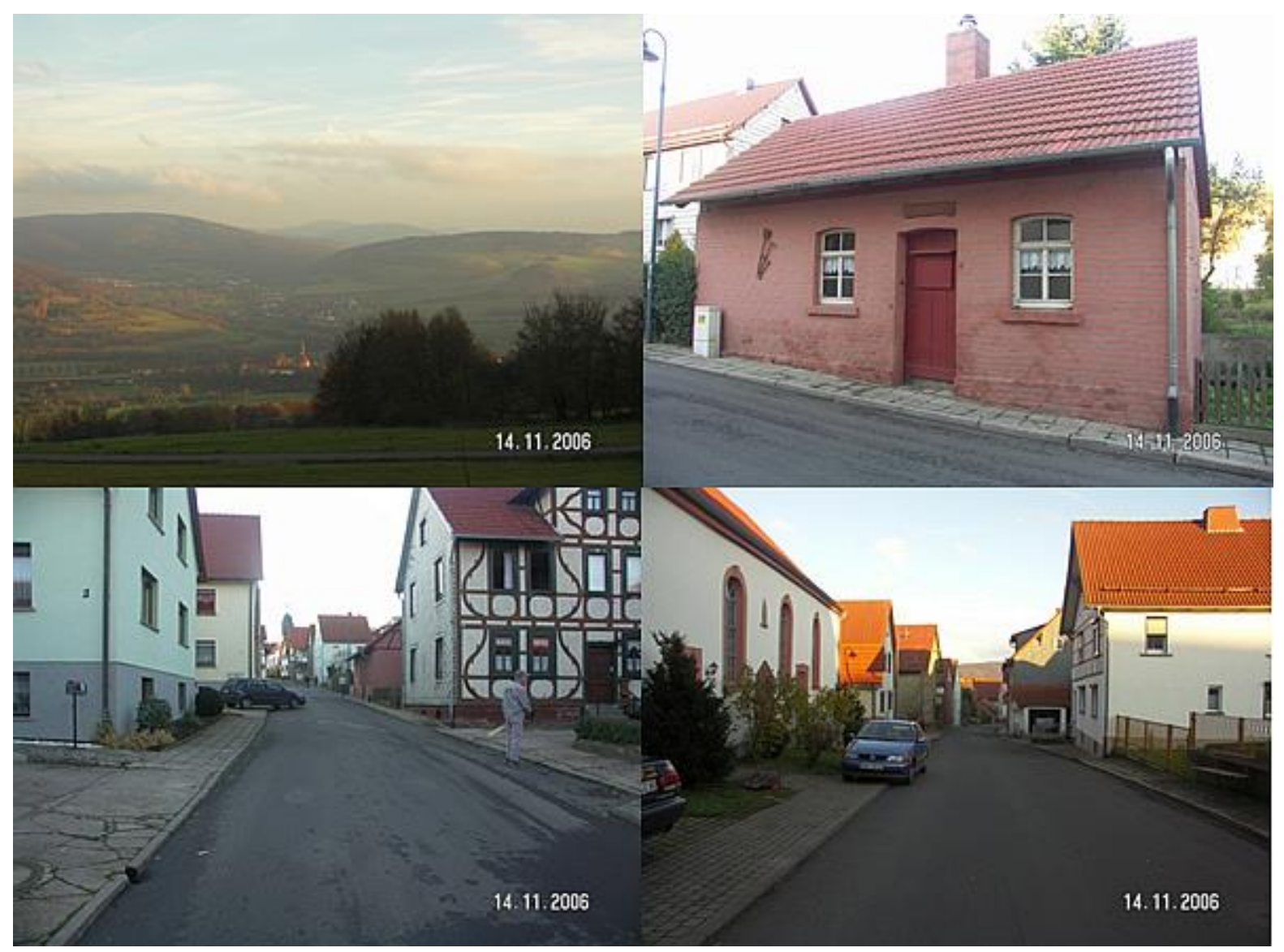

Fig 6. Impressions of Brunnhartshausen.

The project regions have been supported by two external consultings. Thereby one consulting attended to Schlieben and Kläden and the other to Glaisin, Lawalde and Brunnhartshausen.

Prior to the development of the touristic offer but after the selection of the model regions a basic status analysis as well as requirements analysis has been conducted by the consultants together with the regions. Thereby the specific touristic potential of the regions has been analysed with the aim to build the village tourism to be developed upon this potential. Nevertheless, the analysis was mainly restricted to the local cultural and natural potentials only, that is, the local attractive features. The demand aspect was not thoroughly considered. So, a critical comparison with already existing destinations the development of unique selling propositions or a cost benefit analysis has not been done (see Fink, Plankl 1998 for more details). 


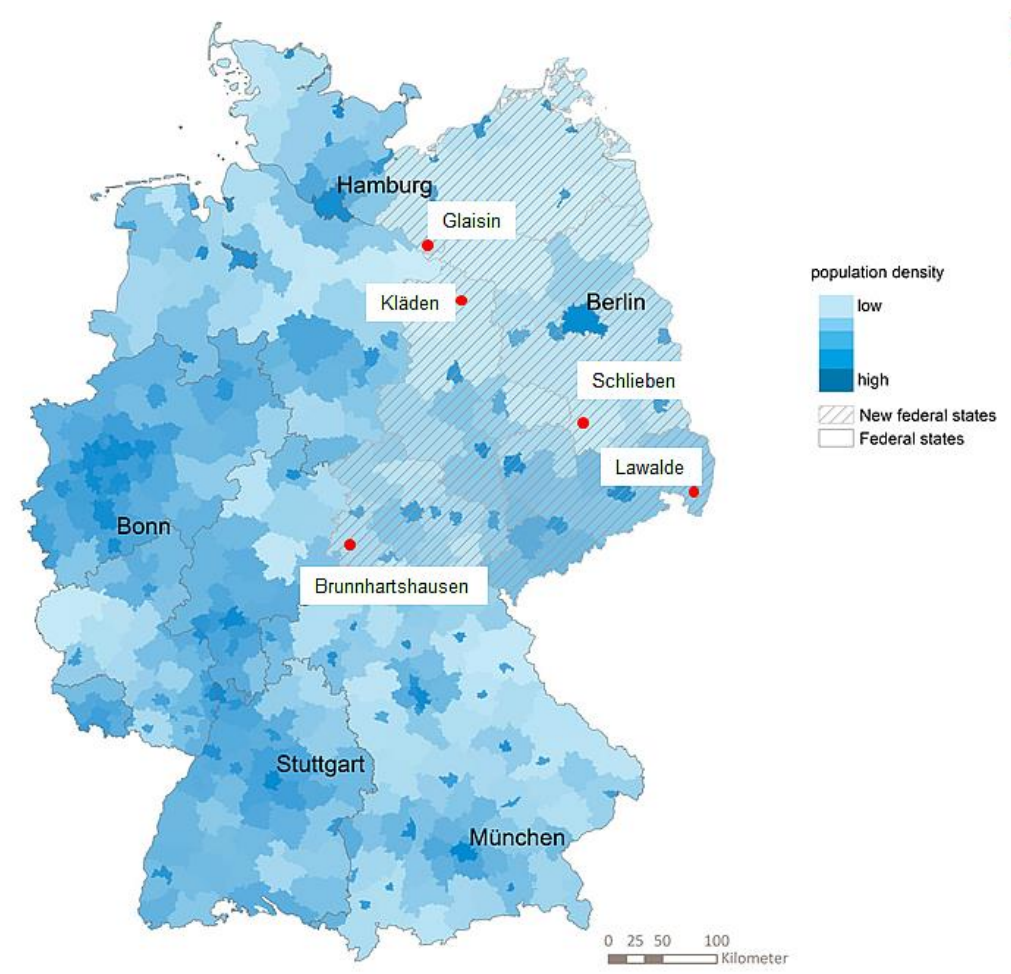

Fig 7. Location of the pilot project areas in eastern Germany.

\subsection{Methods of research}

In order to analyse the impacts of the model-project the development of the model villages was analysed via four methodological approaches between 2005 and 2009. Thereby the analysis focused on the achievement of the aims of the model project already mention ed in section 3.1. The research started with field studies in the five areas. Thereby the current state of the tourist development was compared with the results of the concomitant research from 1995 to 1998 to record the development undergone since 1995. For this purpose about 12 local key persons, such as mayors or head officials, were questioned in guided interviews. The interviews focused mainly on the local experts assessments of the success or failure of the model project, available tourist offerings as well as on subsequent developments rooted in or triggered by the model project. In addition, personal impressions of the areas were registered through field visits.

Through a standardized survey and the comparison of the results with findings of a survey conducted in 1996, it was investigated how the citizens of the model-villages assess the achievement of the model-project objectives today and which role they attribute to the model-project within the undergone regional development. A total of 60/61 citizens per area were questioned personally with a standardized questionnaire. The selection of the participating persons was based on a stratified random sample. The main part of the questionnaire comprised questions about the probands knowledge of the model project and, if applicable, involvement in working groups developed within the scope of the model project, the probands assessment of the impact of the model project for regional and tourism development, the probands assessment of the current development in comparison to the situation prior to the model project.

Within the scope of a two-day expert-workshop with 16 actors from the five model-project villages (from administration, tourism, the former project staff) the pilot project was discussed in retrospect according to the opinion of the experts. To activate the discussion the results and conclusions of the standardized survey was presented and discussed with the participants at the beginning of the workshop. Subsequently the participants were invited to discuss experiences in tourism as well as economic development since the end of the model project, to discuss the role of funding for the regional economic and touristic development and to discuss the role of public participation for these processes. 
A detailed overview of the themes discussed as well as the results is given by Neumeier, Pollermann and Jäger (2011).Finally, based on these results two model-project areas identified as successful (Glaisin, Kläden) were selected for further in-depth qualitative case studies by means of theoretical sampling. Thereby information on the achievement of the aims regarding contents and methods, as well as factors of success or failure of the envisioned tourism development were collected (see Neumeier, Pollermann, Jäger (2011) for details) based on narrative interviews with local actors currently participating in rural development efforts and actors formerly involved in the model-project (15 interviews per area, sample based on theoretical sampling). The narrative interviews have been recorded and transcribed. The transcriptions have been categorized according to the rules of the thematic coding proposed by Hopf (cf. Kuckartz 2005). The analysis of the interview data has been done according to the method of structural context analysis (in specific by the method of the "content structuring context analysis") proposed by Mayring (2007).

\subsection{Results for tourism and rural development}

Altogether the examinations provided the following picture: In all areas the model-project functioned as the cornerstone for further tourist development but had limited reach. One reason for this limited reach might be attributed to the absence of a real, economically sound market analysis focusing on the local attractive features that could be marketed instead of taking into account the demand prior to the selection of the regions as project regions. Local networking activities between the tourist activities and the development of tourism marketing methods could be achieved. All pilot-villages except one established a seasonally operated tourism bureau. Local tourist alliances could be created and a positive attitude towards tourism could be communicated to the citizens in four of the five project-villages. So the project contributed to the emergence of so called social innovations (c.p. Neumeier 2012) as result of changes in the people's minds as kind of sociological changes caused by the participatory approach. That is, new ways of organizing leading to the development of a tourist offering adapted to the regional potentials.

As another outcome it could be observed that in all project-villages a few privately run bed and breakfasts were established which allow the operators to add to their household income. The standard of these establishments ranges from very basic (room with an appearance of an old fashioned bedroom just abandoned by some former family member) to normal (room with modern furniture, private bathroom and television). Furthermore, the villages succeeded to establishing cultural offerings and leisure time facilities. Examples are historical bakeries, nature trails, museums of local history, outdoor markets of local importance or culture-barns which are largely still used today. Thus the infrastructure created allows cultural offerings to be provided for the local citizens as well as potential guests (concerts, readings, theatre events, exhibitions).

However a close consideration also reveals that the infrastructure created is mainly used by local citizens as well as day-time tourists from the closer catchment areas of the regions. Thus the tourist infrastructure created in view of the model-project mainly serves local recreation and day-time visitors. Beyond this it is only of limited touristic importance. In addition, the infrastructure is, in part, maintained by subsidies like LEADER, (a bottom-up oriented funding scheme for collaboration of different stakeholders in regional development processes within the rural development programmes funded by the European Community) - without a sustainable operational concept for the time after the expiration of the funding.

Thus uncertainties about the future perspectives of the establishments exist. Nevertheless, it appears that this infrastructure also plays an important role in the shaping of a local identity.

The extent to which tourist development has, according to the local citizens, generated longlasting impacts is illustrated in Table 1. The table summarizes the main results of the 2007 survey. By referring to the 1996 survey, the table depicts the citizens' view of the impact of tourism in the pilot-villages as an arithmetical mean. The arrows illustrate the comparison of the supposed impact between 1996 and 2007. 


\begin{tabular}{|c|c|c|c|c|c|c|c|c|c|c|c|c|c|c|c|c|c|c|}
\hline & \multicolumn{3}{|c|}{$\begin{array}{l}\text { Brunnharts- } \\
\text { hausen }\end{array}$} & \multicolumn{3}{|c|}{ Glaisin } & \multicolumn{3}{|c|}{ Kläden } & \multicolumn{3}{|c|}{ Lawalde } & \multicolumn{3}{|c|}{ Schlieben } & \multicolumn{3}{|c|}{ Gesamt } \\
\hline & 96 & 07 & cp. & 96 & 07 & cp. & 96 & 07 & cp. & 96 & 07 & $\mathrm{cp}$. & 96 & 07 & cp. & 96 & 07 & cp. \\
\hline $\begin{array}{l}\text { Tourism contributed to } \\
\text { an improvement of } \\
\text { income and working } \\
\text { opportunities }\end{array}$ & 3,3 & 4,5 & עע & 3,2 & 3,0 & $\rightarrow$ & 3,3 & 3,5 & $\rightarrow$ & 3,1 & 3,1 & $\rightarrow$ & 3,7 & 3,9 & $\rightarrow$ & 3,3 & 3,6 & $\rightarrow$ \\
\hline $\begin{array}{l}\text { Tourism caused } \\
\text { an increase in sales in } \\
\text { gastronomy and retail }\end{array}$ & 2,6 & 3,7 & עיע & 3,0 & 1,9 & $\pi$ & 2,7 & 3,2 & $y$ & 2,4 & 2,7 & $\rightarrow$ & 2,6 & 3,6 & ע & 2,7 & 3,0 & $\rightarrow \rightarrow$ \\
\hline $\begin{array}{l}\text { The extension of } \\
\text { the tourism leads to } \\
\text { a better order situation } \\
\text { for craft enterprises }\end{array}$ & 3,8 & 4,0 & $\rightarrow$ & 3,5 & 3,2 & $\rightarrow$ & 3,3 & 3,8 & $y$ & 2,8 & 3,7 & $y$ & 3,9 & 4,4 & $y$ & 3,5 & 3,8 & $\rightarrow$ \\
\hline $\begin{array}{l}\text { Tourism contributes to } \\
\text { a good accessibility }\end{array}$ & 4,0 & 4,1 & $\rightarrow$ & 3,3 & 2,3 & $\pi$ & 3,4 & 3,8 & $\rightarrow$ & 3,4 & 3,6 & $\rightarrow$ & 4,1 & 4,4 & $\rightarrow$ & 3,6 & 3,6 & $\rightarrow$ \\
\hline $\begin{array}{l}\text { Tourism contributes to } \\
\text { a maintenance of } \\
\text { public facilities within } \\
\text { the region }\end{array}$ & 4,5 & 4,9 & $\rightarrow$ & 3,5 & 3,7 & $\rightarrow$ & 3,9 & 4,0 & $\rightarrow$ & 3,4 & 3,6 & $\rightarrow$ & 3,9 & 4,2 & $\rightarrow$ & 3,8 & 4,1 & $\rightarrow$ \\
\hline $\begin{array}{l}\text { Tourism enables } \\
\text { the development of } \\
\text { bicycle and hiking } \\
\text { trails }\end{array}$ & 2,7 & 3,1 & $\rightarrow$ & 2,2 & 1,9 & $\rightarrow$ & 2,0 & 2,7 & $y$ & 2,3 & 3,1 & $y$ & 2,7 & 2,7 & $\rightarrow$ & 2,4 & 2,7 & $\rightarrow$ \\
\hline $\begin{array}{l}\text { Tourism contributed to } \\
\text { an attractive village } \\
\text { scenery }\end{array}$ & 2,9 & 2,8 & $\rightarrow$ & 1,9 & 1,8 & $\rightarrow$ & 2,4 & 3,1 & ע & 1,8 & 2,4 & $y$ & 2,9 & 3,2 & $\rightarrow$ & 2,4 & 2,7 & $\rightarrow$ \\
\hline Total / Arithmeticmean & 3,4 & 3,9 & $y$ & 2,9 & 2,5 & $\rightarrow$ & 3,0 & 3,4 & $\rightarrow$ & 2,7 & 3,2 & $y$ & 3,4 & 3,8 & $\rightarrow$ & 3,0 & 3,4 & $\rightarrow$ \\
\hline
\end{tabular}

Tab 1. Assessment of the perceived impacts of tourism development - comparison between 1996 and 2007.

$96=$ survey of 1996; 07 = survey of 2007.

cp.: compare between 96 and 07 surveys

$1=$,applies completely“; $5=$,does not apply at all“

Differences of the arithmetic means (d) of the ratings of the perceived impacts from 2007 and 1996

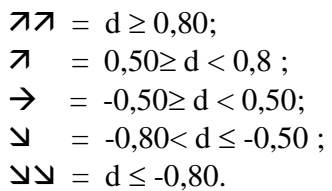

According to the citizens' rating, the village's appearance as well as bicycle and hiking paths were assessed most positively, followed by growth in sales in gastronomy and retail in both the 1996 and 2007 surveys. The hope that the tourism could have a positive impact on the preservation of public facilities and contribute to a good accessibility has, according to the majority of questioned citizens, not been fulfilled. The same is true for positive impacts on craft enterprises. Thus according to the questioned citizens' perception the economic impacts of the model-project are not sufficient to effectively support the regional development. With regard to the comparison of the surveys from 1996 and 2007 it can be recognized that the results are slightly worse in 2007 than in 1996. Thus one can conclude that in the ten years since the ending of the model-project, no positive self-dynamic took place with regard to tourist development, although most impacts can be considered as relatively stable. Another indication for the minor economic importance of tourism is given by the survey results. Questioned if they derive income from tourism over all project regions only 11 people (Brunnhartshausen 4, Glaisin 2, Kläden 0, Lawalde 3, Schlieben 2) which amounts for $3.6 \%$ from the 302 people questioned answered this question with yes 33 .

Thus, according to the questioned citizen's perception the economic impacts of the modelproject are not sufficient to effectively support the regional development.

Last but not least the minor economic importance of tourism was confirmed within the scope of the expert workshop where all experts agreed that income maintenance through village tourism 
could not be achieved as tourism in the classical sense does not take place in the regions. So, it can be concluded, that in none of the five pilot-villages a significant income maintenance, as anticipated by the title of the pilot project, could be reached (but because small businesses with less than nine beds, which are the main offerings in the model villages, in Germany are not included in main tourist statistics, it was not possible to give clear data about the number of tourists). Furthermore, the impact on other economic sectors is as already shown in table 1 also quite small. One reason for the low tourism performance could be the lack of an effective marketing strategy thoroughly considering the demand, which is anyhow not easy to develop in such small destinations like a single village.

So, tourism is a sideline income in all model-areas and, at best, complements the income of a handful of persons providing accommodation facilities. However via tourism it is possible to offer low paid (seasonal) jobs and jobs on the basis of job creation schemes.

Nevertheless, his has to be judged ambivalently: The psychological impact of the participation at gainful employment can be positive for the people affected. At the same time such jobopportunities offer almost no sustainable perspectives or continuity. Apart from small scale rural tourism complementing the income of a handful of persons mainly providing accommodation facilities no further-reaching economic impacts could be observed in the model areas. And no evidence for a further-reaching regional networking (in tourism and economy) could be observed in the accompanying research. The expectations for enduring income maintenance that could function as a substitute for jobs lost as a result of the socioeconomic structural change linked with the development of a rural tourism have not been met.

But according to the empirical results, today, tourism opportunities, as well as constraints, are seen quite realistically in the areas investigated. The initial disappointment about the negligible economic impacts has changed. Most of the pilot-villages are quite satisfied with the touristic development and share the view that the model-project, as well as the touristic emphasis, was important for the overall rural development process.

Based on the results obtained, the concomitant research came to the same conclusion as it showed that the model-project has triggered quite a few real material and immaterial impulses with regard to village development. Examples for material impulses are the introduction of a binding regulation concerning how buildings have to be built or maintained in the village centre so that they fit the traditional regional architectural style in Glaisin; the renovation of a deteriorated historical village inn in the centre of Glaisin, or the development of a so called cultural barn, a renovated traditional sheep shelter now used to offer cultural events like concerts or cabaret to the local population in Kläden. Examples for immaterial impulses are the strengthening of the space-oriented identity in Glaisin leading to a higher place attachment as well as a consolidation and enhancement of the village's local identity or the motivation of citizens to campaign for regional interests and actively participate in rural development in Kläden. Also, in all project regions the pilot project contributed to a stringent and coordinated use and utilization of different development subsidies and promotion of collaboration between local actors. Furthermore guided interviews with officials and tourism experts in the projectvillages as well as an analysis of the expert workshop showed that the pilot-project, due to the application for funds for rural development, imparted knowledge that was crucial for the subsequent development efforts of the areas as well as private tourism actors. Although the initial work-groups established during the model-project vanished, the research showed in nearly all project-villages that the neo-endogenous development approach contributed to an activation of the local public that continues to have a positive effect. As an example, subsequent to the pilot project in one part of Kläden, an association was established that applies its energies to the development of the neighbourhood. Similarly, in the other pilot regions communities of interests have been developed triggered by the pilot-project, too. Against the background of the East German history of the project regions, such effects are quite remarkable since such public participation was not common in the former German Democratic Republic (GDR).

All in all the examinations revealed that within all model-villages, the pilot-project contributed to a promotion of the different actors and interest-groups and a networking of the different 
individual initiatives within the areas, that in some cases even resulted in social innovations (e.g. founding of an association for neighbourhood development or the founding of an association maintaining a cultur-barn in Kläden, the involvement of the public in the decisions of the local council in Glaisin, the maintenance of seasonally operated tourism information). Last but not least, the realized cultural offerings create an opportunity to provide cultural events for the local population (readings, theatre, concerts) as well as potential guests.

\subsection{Discussion of the findings}

If we reflect the above summarized findings against the tourism aims of the pilot project (cp. section 3.1) one would conclude that economically, the model-project was not very successful, since the main aim to generate income and to stabilize the regions' economies via tourism could not be achieved.

The contrary is true for the methodical aims. As shown in all model-villages, the pilot-project contributed to an activation of public participation, triggered self-contained activities and initiation, and ensured at least some long-term commitment to the own local area. So inducing a socio-political change was a relevant impact (especially the development of a culture of participation contrasting structures and mental-models prevailing during GDRtimes).

Although infrastructure - like local history museums, community centres, instructional trails through a vineyard, historical bakehouses, outdoor swimming pools, outdoor chess and table tennis facilities or even spiral herb gardens to name only a few - do not have the potential to function as sustainable tourist attractions from a purely economic point of view. Such infrastructure belongs to local recreation and although it is of great importance for the local population and the village's self-image, it does not have any noteworthy touristy and economic effects nor does it influence the external image of a region, as the examples of the model-villages clearly showed (Neumeier et al., 2011 p. 40).

But taking an anthropological point of view, the picture will be quite different. Here, infrastructure - like local history museums, community centres or the other just mentioned attractions contributes to the attractiveness of the rural region, to an enhancement of the local identity and establishes a certain kind of integrated rural tourism (Cawley and Gillmor, 2008) which does not have the potential to contribute in an economic manner, but rather to an equally important overall rural development by promoting socio-political change.

Judging the success or failure of the model-project, or respectively rural-tourism development, based only on its economic impact leads to the conclusion that the modelproject was not successful.

But, as we have seen, the pilot project had quite a few social and cultural implications important for the development of the model-villages, like enhancement of the local identity, a stringent and coordinated use and utilization of different subsidies of development, and promotion of collaboration between local actors. So, concluding that the model-project and effort to develop a rural tourism did not contribute much to rural development is only partially correct. The successes in the sense of a socio-political change are the creation of actor networks, changes in attitudes to grassroot participation processes as well as the development of a higher self-confidence and a higher place attachment.

Although the example of the model-project showed that in regions structured similarly to the model villages, which do not have or are unable to develop unique selling points, no great economic leaps forward are likely. The research showed that via the medium tourism, promising opportunities exist for promoting regional development or enhancing the regions' attractiveness for its citizens as well as potential guests (e.g., by establishing a local recreation infrastructure). Consequentially this leads to the conclusion that if a region succeeds in initiating governance processes, activating the reflection about alternative adapted regional development opportunities, or stringently coordinating rural development projects via tourism, tourism is one possible option to trigger development impulses and 
efforts. Thereby it has to be kept in mind that tourism is only one possibility amongst others to trigger regional development impulses.

But as observations in the project areas have shown tourism seems to have a special potential to function as nucleus for participatory processes as well as regional development processes. The reasons are not yet fully clear, but the perception of tourism as something positive, that most people associate with their own experiences, seems to play an important role here. But presently this is only an assumption that should be questioned more in depth in the future. Up to now it is certain that seeking potentials for marketing an area as a tourist destination can support a process of thinking about endogenous potentials of the region in general. Altogether, the empirical results show that tourism is not the solution, but only a small contribution, and beyond direct impacts, also a contribution to seeking other solutions in collaborative way.

\section{Conclusions}

After we considered the role of rural tourism as promoter of rural development theoretically as well as based on findings from the pilot project, in this section we will summarize the main findings about the role of rural tourism as a factor of regional development first. Afterwards we will discuss whether the assumptions made in section 2 are useful for explaining the outcome of the model-project by analysing the role of the potentials of success and support via funding programs.

\subsection{Rural Tourism as promoter of rural development - synthesis}

It should also be mentioned that it is not possible to really weigh the possibilities induced by tourism against other options from different economic sectors here, because this was not the subject of the research. But together with the results from the literature review, the findings help to clarify the possibilities to foster rural development by tourism. In addition it has to be mentioned that the rural areas examined were quite small-scale. In such areas it is problematic to reach a certain critical mass of tourists (necessary for an economically successful tourism).

Nevertheless, the considerations above allow the following conclusions due to the implications for rural tourism as factor of regional development:

An analysis of the role of rural tourism in rural development should focus on the conceptualisation of rural tourism in a wider sense. The empirical results showed that local recreation is important for rural tourism, because possibilities for tourism with large numbers of overnight-stays are limited in many rural areas. Furthermore the local perception of regional actors also depends on features like cultural offerings, which are only important for local recreation, but which are not attractive enough to attract many visitors external to the region (compare Figure 3).

Diversification into tourism will not be able to save structurally weak peripheral rural areas by providing job alternatives or noteworthy alternative income possibilities. This was clearly proven for regions with no major attractions like the five pilot villages. To judge the potential of tourism for rural development one has to remember that rural areas are not all to the same extent suitable for rural tourism intended to generate noteworthy economic effects. Especially peripheral rural areas will most likely have difficulty in developing an economically successful form of rural tourism.

Thus, to realistically estimate the potentials for developing a successful rural tourism, the building blocks of the tourist attractiveness mentioned earlier should be kept in mind. In order to create economically successful tourism, the shaping of every single building block must be duly considered.

Although the areas of the pilot project were not very suitable for tourism, at all locations some aspects of socio-political change became visible. So an increase in a regional sense of identity could be seen, as well as an activation of local actors, and an increase of social capital. While improving networks and social relations is not alone sufficient for supporting 
economic performance, it is nevertheless a necessary 'ingredient' for successful (economic) development as it has the potential to enhance further benefits for the overall development (Agarwal et al., 2009).

\subsection{Potentials of success in the pilot villages?}

Altogether the considered empirical findings of the pilot project mirror the potentials of success as they were explained in section 2.3 (see Figure 3).

Thus, the activation of public commitment via public participation processes, the importance of key actors, the potential of external counselling and the necessity for appropriate/regionally adapted content concepts have been confirmed.

But the pilot project also revealed problems typical for programs designed to promote rural development. Examples are the development of a "support-mentality," the lacking of stability in participation processes and projects as well as the lacking of concepts of how to continue the achievements after the ceasing of the support.

The importance of the adaption to the initial situation (strategy-fit) has been confirmed for both the conceptual aspects (e.g., consideration of the realistic tourist potentials) and the development process (e.g., due to the development of public participation methods). But there was paid little attention to the demand side of tourism: so they should spend more energy on a market analysis and develop a marketing strategy. As a single village is too small to effectively do this, this could be done as a part of a wider destination management process or by a cooperation with villages from different regions.

Within the model villages the framework conditions of the pilot project definitely contributed to an advancement of the six factors of success (see Table 2). On the other hand it is also possible to identify weaknesses of the pilot project. Here two main problems could be identified that most likely prevented a real success of the pilot project in terms of the ambitious task to achieve income maintenance through village tourism: (1) An improper strategy-fit (regions not qualified for developing an economically successful tourism) led to an unfavourable development of the quality of the concept. Even if the other potentials of success had been invariably met, this would have limited the overall success of the pilot project. (2) The initially positive development of the potentials of success was not durable in the end. For example, the commitment of the participating actors declined once the organizational structures established within the pilot project ceased to exist. Here the time frame of the self-help activation was too short, or incentives for permanently implementing local activities of the locals were not established. 


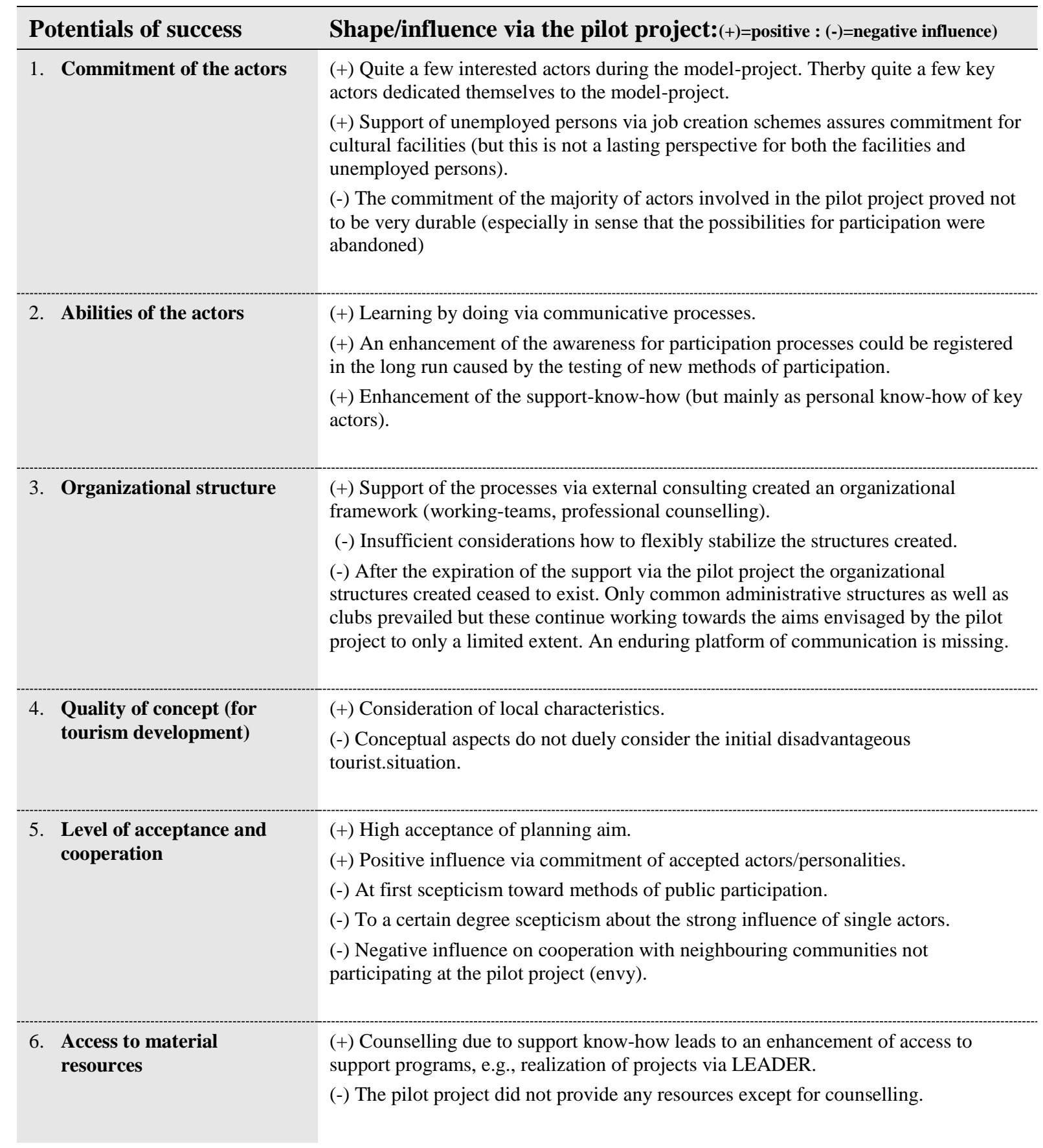

Tab 2. Influence of the pilot project on factors of success.

\subsection{Support via funding programs or pilot projects?}

In this context it is important to consider the following first: A funding program or a pilot project alone cannot create success for regional development, but it can give support and create a framework that makes success highly probable. Possibilities for this are shown in Table 3.

It is possible to estimate whether a funding program can contribute to a successful development by observing the influence of this funding on the potentials of success.

In general a funding program can contribute in the following different ways to all of the six potentials of success (identified by the research about the pilot project, in addition reflected by results of the evaluation of LEADER or similar support schemes in Germany (Pollermann et al., 2013; McAreavey and McDonagh, 2010; Neumeier et al., 2011). 


\begin{tabular}{|l|l|}
\hline Potential of success & Support via funding program (+) / possible negative impacts (-) \\
\hline $\begin{array}{l}\text { 1 Commitment of the } \\
\text { participants }\end{array}$ & $\begin{array}{l}\text { (+) Support through staff (important for volunteers) } \\
\text { (-) bureaucratic task and high complexity of funding conditions can cause } \\
\text { exhaustion }\end{array}$ \\
\hline $\begin{array}{l}\text { 2 Abilities of the } \\
\text { participants }\end{array}$ & $\begin{array}{l}\text { (+) Learning by doing; special measure for qualification, rural networks } \\
\text { (seminar, publications); } \\
\text { (+) exchange between different rural areas }\end{array}$ \\
\hline $\begin{array}{l}\text { 3 Organisational } \\
\text { structure }\end{array}$ & $\begin{array}{l}\text { (+) Financing staff } \\
\text { (+) Guideline about structures (for example the 50-50-quota between } \\
\text { public and private actors in the decision-making body as statutory } \\
\text { provisions by LEADER) } \\
\text { (-) if the working of staff is temporally limited to a few years, this could } \\
\text { lead to a lack of continuity }\end{array}$ \\
\hline 4 Quality of concept & $\begin{array}{l}\text { (+) Guideline for key contents } \\
\text { (-) to narrow provisions as funding conditions }\end{array}$ \\
\hline $\begin{array}{l}\text { 5 Level of acceptance } \\
\text { and cooperation }\end{array}$ & $\begin{array}{l}\text { (+) Additional money supports collaboration (no problems with "hard } \\
\text { interest conflicts"; nobody loses) } \\
\text { (-) envy of (not financially supported) neighbour regions }\end{array}$ \\
\hline $\begin{array}{l}\text { 6 Access to material } \\
\text { resources }\end{array}$ & $\begin{array}{l}\text { (+) Money for projects and staff } \\
\text { (-) be careful with "development of a support-mentality" } \\
\text { (-) funding can favour the question "what is fundable" instead of "what is } \\
\text { most useful" }\end{array}$ \\
\hline
\end{tabular}

Tab 3. Contribution of a funding program to the potentials of success.

\section{Recommendations: Take advantage of opportunities, consider the constraints}

There are limitations, but also prospects for rural development via rural tourism. To support finding a suitable way to deal with the limitations and opportunities in practice, now some general hints regarding the core questions of this article "where and in how rural tourism can contribute to rural development?" are considered. To answer the "where?" suggestions about the adaption of the strategy to different regions are made. Regarding the "how" suggestions for an appropriate participative planning approach as well as shaping of funding schemes are given.

\subsection{Suggestions for adapting the strategy to the regional characteristics}

Different potentials for rural tourism exist for different rural areas. The main distinguishing features are the accessibility and the region's touristic attractiveness. To make possible constraints visible Figure 3 summarized which forms of rural tourism are most appropriate for which kind of rural regions. Especially remarkable is:

Areas with low or no cultural or natural tourist potential can, by valorizing their specific characteristics, create an integrated rural tourism contributing to a reflective recreational activity oriented on authentic experience. But the overall economic impact of such an extensive form of tourism as described in the previous sections is supposed to be quite low, which was clearly the case in the pilot project. Its success has to be measured based on criteria other than its economic effects.

Highly accessible areas and areas in the urban hinterland of cities might attract more tourists than peripheral rural areas even if their tourist potential is lower.

Especially highly accessible rural areas in the urban hinterland might be able to develop economically successful rural tourism based on day tourism. Here (and only here) infrastructure actually belonging to local recreational offering might attract a critical mass of potential tourists from outside of the own region. In contrast this is quite unlikely for poorly accessible peripheral rural regions. 
For rural areas like the ones in the pilot project (deep rural, relatively low attractiveness) a combination of rural tourism with the search for other endogenous potentials and enhancement of the quality of life seems to be most suitable.

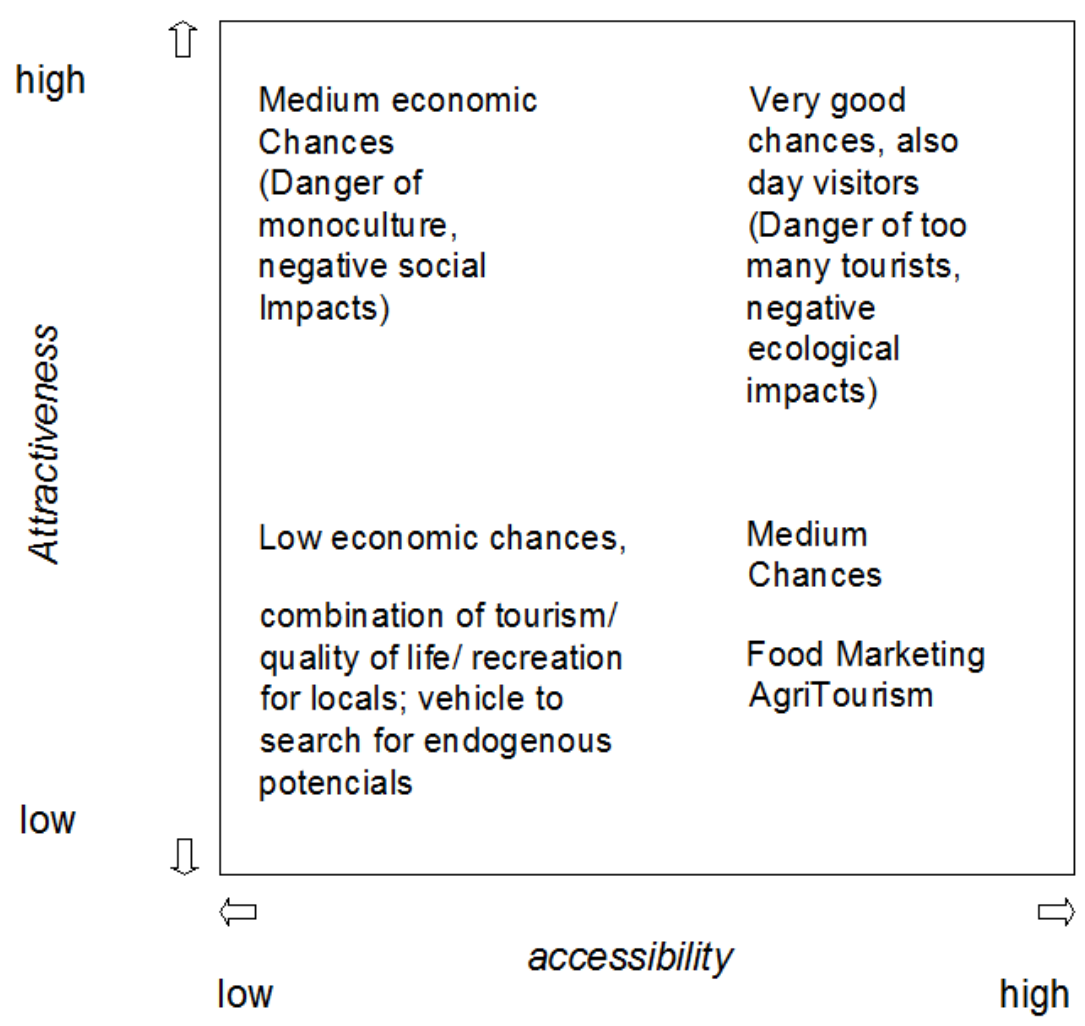

Fig 8. Degree of attractiveness and accessibility and implications for rural tourism.

\subsection{Suggestions for a participative planning approach}

The main principles of a promising participative approach (see theoretical section) could be confirmed by the findings from the pilot project. For the special conditions in the context of rural tourism, the following factors are especially important:

The potentials of success should be considered when implementing a long-term oriented planning approach. Major recommendations are shown in Figure 9. An important aspect is, that if only one single potential out of the six potentials is badly developed this will be a crucial constraint for the whole process.

The limitations, for a suitable "strategy fit” should always be kept in mind, in this context the actors should be careful: outside conditions can change and then the planning-strategy has to be changed, too. So an observation of general tourist trends on the demand side as well as the modifications of regional conditions due to demographic change is a constant task.

As also the empiric results from pilot projects showed a long-term motivation and commitment are especially important for the planning processes and the establishment of wider actornetworks within the area, for the design of the planning-procedure an overlapping of planning, on the one hand, and putting into practice, on the other hand, is recommended (Pollermann 2004). To take advantage of this approach, it is vital to concentrate on projects which are easy to implement and for which a large consensus exists.

In order to enhance the transparency of such processes the Internet could also be used as a medium, for example via Public Participatory GIS as an actor of rural development (see for example Herrmann and Neumeier, 2007).

Finally a procedure for a process-integrated evaluation of the planning- and implementation processes is strongly recommended. 


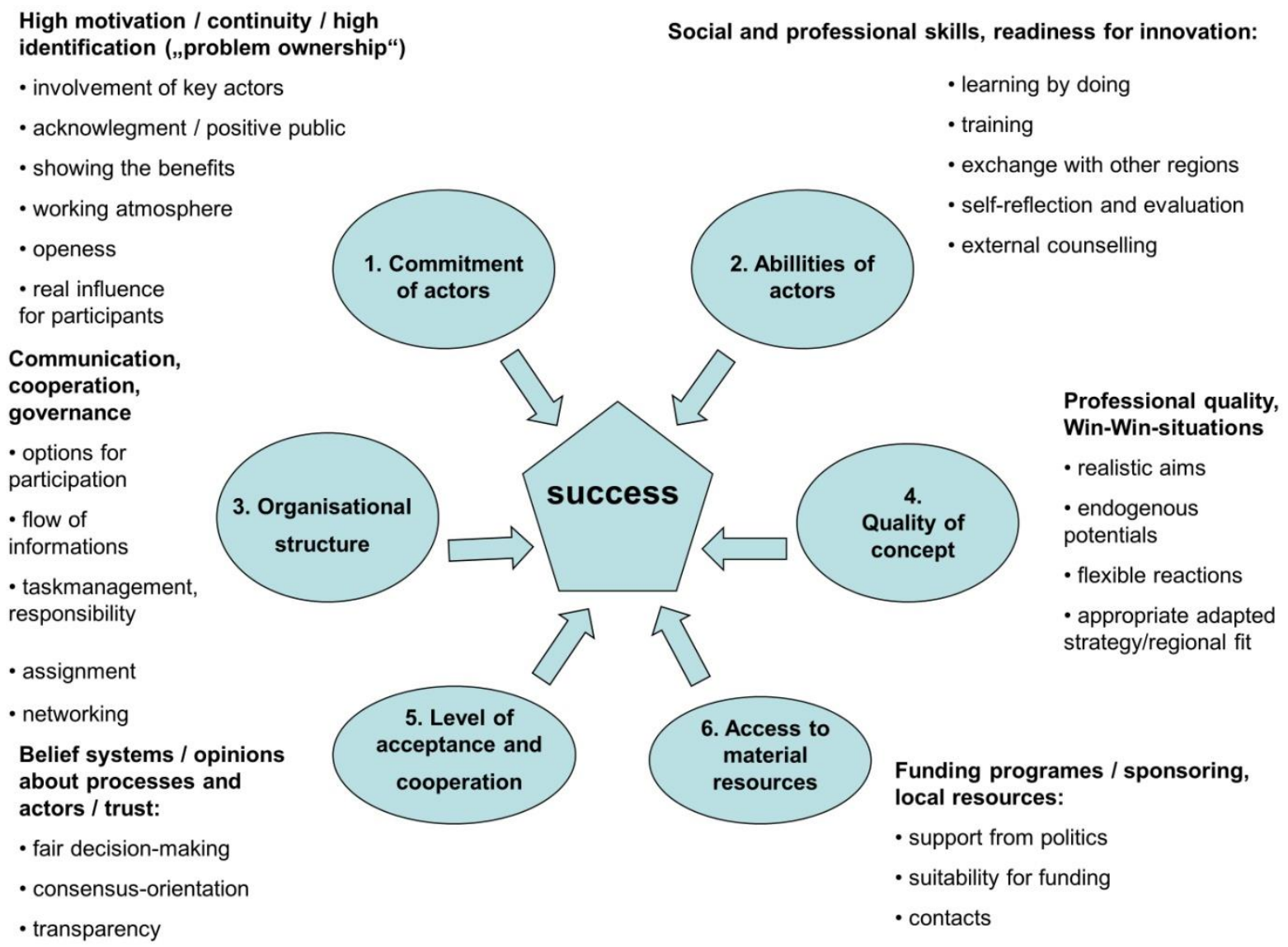

Fig 9. Six Potentials of success for cooperative regional development processes.

\subsection{Suggestions for a support via funding}

The role of tourism for regional development and the possibilities to endorse an economically successful tourism through funding programs should not be overestimated. But attempts for using tourism as a vehicle for participation, collaboration and finding ways to use endogenous potentials are also reasonable in rural areas without great touristic potentials. Regarding these options it is especially essential to give local actors a major role. Ideally, a system of support should be introduced that enables a project-funding whereas the expected success with regard to the individual regional prerequisites and development aims is the main criteria for the granting of subsidies, instead of concentrating on strict 'globally' specified conditions and modalities. Thus, decision processes could be handed on to lower levels in order to foster debureaucratisation. Thereby the evaluation of rural development programmes shows, that bureaucratic, narrow funding conditions are a major constraint for participative approaches like LEADER (Pollermann et al. 2013; Dax et al., 2013). For larger projects a market analysis should be a precondition for funding.

Furthermore via a funding regulated by the local actors themselves, a competition for the best ideas could develop. Thereby it is also important to include potentially critical civic actors in the development processes and to establish an open participation process.

Finally we want to summarize, that in most rural regions tourism alone is not the solution for mitigating rural development divides and inducing noteworthy economic growth. But instead it can make a valuable contribution to an integrated approach to rural development by functioning as a vehicle for participation, collaboration and finding new innovative ways to use endogenous potentials which might result in advancements in rural development. 
[1] Agarwal, S., Rahman, S. \& Errington, A. (2009). Measuring the determinants of relative economic performance of rural areas. Journal of Rural Studies, 25(3), 309-321. DOI: 10.1016/j.jrurstud.2009.02.003.

[2] Belletti, G., Brunori, G., Marescotti, A., Berti, G. \& Rovai, M. (2013). Is rural tourism sustainable? A reflection based on the concept of 'rural tourism configurations'. In: Figueiredi, E., Raschi, A., Eds. Fertile Links? Connections between Tourism Activities, Socioeconomic Contexts and Local Development (pp. 93-106), Firenze University Press.

[3] Benthien, B. (1995). Touristische Entwicklungsmöglichkeiten der neuen Bundesländer. In: Moll, P., Ed., Umweltschonender Tourismus - Eine Entwicklungsperspektive für den ländlichen Raum (pp. 150-115). Bonn: Kuron.

[4] Blackstock, K. (2005). A critical look at community based tourism. Community Development Journal, 40(1), 39-49. DOI: 10.1093/cdj/bsi005.

[5] Borg van der, J. (2008). Place Marketing, Governance and Tourism Development. Or How to Design the Perfect Regional Tourist Board? Venezia: Ca' Foscari University.

[6] Brandth, B. \& Haugen, M. (2011). Farm diversification into tourism - Implications for social identity. Journal of Rural Studies, 27(1), 35-44. DOI: 10.1016/j.jrurstud.2010.09.002.

[7] Cawley, M. \& Gillmor, D. (2008). Integrated rural tourism: Concepts and Practice. Annals of Tourism Research 35(2), 316-337. DOI: 10.1016/j.annals.2007.07.011.

[8] Darbellay, F. \& Stock, M. (2012). Tourism as complex interdisciplinary research object. Annals of Tourism Research, 39 (1), 441-458. DOI: 10.1016/j.annals.2011.07.002.

[9] Dax, T., Strahl, W., Kirwan, J. \& Maye, D. (2013). The LEADER programme 2007 - 2013: Enabling or disabling social innovation and neo-endogenous development? Insights from Austria and Ireland. European Urban and Regional Studies. DOI: $10.1177 / 0969776413490425$.

[10] Deller, S. (2010). Rural Poverty, Tourism and Spatial Heterogeneity. Annals of Tourism Research, 37(1), 180-205. DOI: 10.1016/j.annals.2009.09.001.

[11] Dong, E., Wang, Y., Morais, D. \& Brooks, D. (2013). Segmenting the rural tourism market. The case of Potter County, Pennsylvania, USA. Journal of Vacation Marketing, 19(2), 181193. DOI: $10.1177 / 1356766712471231$.

[12] Dwyer, L., Forsyth, P. \& Spurr, R. (2004). Evaluating tourism's economic effects: new and old approaches. Tourism management 25 (3): 307-317. DOI: 10.1016/S02615177(03)00131-6.

[13] Figueiredo, E. \& Raschi, A. (2013). Fertile Links? Connections between tourism activities, socioeconomic contexts and local development in European rural areas. In: Figueiredo, E. \& Raschi, A., Eds., Fertile Links? Connections between Tourism Activities, Socioeconomic Contexts and Local Development (pp. 7-16). Firenze University Press.

[14] Fink, M. \& Plankl, R. (1998). Wissenschaftliche Begleituntersuchung zum Modellvorhaben "Einkommenssicherung durch Dorftourismus". Bonn: Bundesministerium für Ernährung, Landwirtschaft und Forsten.

[15] Flanigan, S., Blackstock, K. \& Hunter, C. (2014). Agritourism from the perspective of providers and visitors: a typology-based study. Tourism Management, 40, 394-405. DOI: 10.1016/j.tourman.2013.07.004.

[16] Gascón, J. (2013). The limitations of community-based tourism as an instrument of development cooperation: the value of the Social Vocation of the Territory concept. Journal of Sustainable Tourism, 21(5), 716-731. DOI: 10.1080/09669582.2012.721786. 
[17] Haugland, S., Ness, H., Groenseth, B.-O. \& Aarstad, J. (2011). Development of Tourism Destinations. An Integrated Multilevel Perspective. Annals of Tourism Research, 38(1), 268-290. DOI: 10.1016/j.annals.2010.08.008.

[18] Haven-Tang, C. \& Jones, E. (2012). Local leadership for rural tourism development: A case study of Adventa, Monmouthshire, UK. Tourism Management Perspectives, 4, 28-35. DOI: 10.1016/j.tmp.2012.04.006.

[19] Herrmann, S. \& Neumeier, S. (2007). The social implications of developing a Web-GIS: observations from studies in rural Bavaria, Germany. In Lovett, A. \& Appleton, K., Eds., GIS for environmental decision making (pp. 241-253). Boca Raton: CRC Press.

[20] Iorio, M. \& Corsale, A. (2010). Rural tourism and livelihood strategies in Romania. Journal of Rural Studies, 26(2), 152-162. DOI: 10.1016/j.jrurstud.2009.10.006.

[21] Jensen-Butler, C., Madsen, B. \& Zhang, J. (2007). Regional Economic Impacts of Tourism: The Case of Denmark. Regional Studies, 41(6), 839-853. DOI: $10.1080 / 00343400701281733$.

[22] Johnston R. J., Gregory, D., Pratt, G., Watts, W. (2000). The dictionary of human geography, $4^{\text {th }}$ edition. Willey - Blackwell.

[23] Jobin, D. (2008). A transaction Cost-Based Approach to Partnership. Evaluation 14(4), 437-465. DOI: 10.1177/1356389008095487.

[24] Kamata, H., Misui, Y. \& Yamauchi, H. (2010). How to attract more tourists? Tourism review, 65(4), 28-40. DOI: 10.1108/16605371011061606.

[25] Komppula, R. (2014). The role of individual entrepreneurs in the development of competitiveness for a rural tourism destination - A case study. Tourism Management 40, 361-371. DOI: 10.1016/j.tourman.2013.07.007.

[26] Korf, B. (2007). Governing bottom-up in rural development. The legitimacy dilemma. In Cheshire, L., Higgins, V. \& Lawrence, G., Eds., Rural Governance. International perspectives (pp. 259-272). London: Routledge.

[27] Kuckartz, U. (2005). Einführung in die computergestützte Analyse qualitativer Daten. Wiesbaden: VS Verlag für Sozialwissenschaften.

[28] Lane, B. (1994). What is rural tourism? Journal of Sustainable Tourism 2(1\&2) 7-21. DOI: $10.1080 / 09669589409510680$.

[29] Leser, H., Haas, D., Moismann, T. \& Paesler, R. (1992). Diercke Wörterbuch der Allgemeinen Geographie. Band 1. München: Dtv Deutscher Taschenbuch.

[30] Lukić, A. (2013). Tourism, Farm Diversification and Plurality of Rurality: Case Study of Croatia. European Countryside, 5(4), 356-376. DOI: 10.2478/euco-2013-0023.

[31] Madsen, B. \& Zhang, J. (2010). Towards a New Framework for Accounting and Modelling the Regional Impacts of Tourism. Economic Systems Research 22(4), 313-340. DOI: $10.1080 / 09535314.2010 .529067$.

[32] Matarrita-Casante, D. (2010). Beyond Growth. Reaching Tourism-Led Development. Annals of Tourism Research, 37(4), 1141-1163. DOI: 10.1016/j.annals.2010.05.004.

[33] Mayring, P. (2007). Qualitative Inhaltsanalyse. Grundlagen und Techniken. Weinheim: Beltz.

[34] McAreavey, R. \& McDonagh, J. (2010). Sustainable Rural Tourism: Lessons for Rural Development. Sociologia Ruralis 51(2), 175-194. DOI: 10.1111/j.1467-9523.2010.00529.x.

[35] Nair, V., Munikrishnan, U. T., Rajaratnam, S. D., \& King, N. (2014). Redefining Rural Tourism in Malaysia: A Conceptual Perspective. Asia Pacific Journal of Tourism Research(early-bird). DOI: 10.1080/10941665.2014.889026.

[36] Neumeier, S., Pollermann, K. \& Jäger, R. (2011). Überprüfung der Nachhaltigkeit des Modellprojekts Einkommenssicherung durch Dorftourismus. Braunschweig: Thünen Institut. 
[37] Neumeier, S. \& Pollermann, K. (2011). Ländlicher Tourismus als Chance? Möglichkeiten und Grenzen der Förderung von ländlichen Tourismus am Beispiel eines Modellvorhabens. Landbauforschung - vTI Agriculture and Forestry Research, 61(3), 161-174.

[38] Neumeier, S. (2012). Why Do Social Innovations in Rural Development Matter and Shouldthey be Considered more Seriously in Rural Development Research? - Proposal for a Stronger Focus on Social Innovations in Rural Development Research. Sociologia Ruralis 52(1), 48-69. DOI: 10.1111/j.1467-9523.2011.00553.x.

[39] Nyaupane, G. \& Poudel, S (2011). Linkages among Biodiversity, Livelihood and Tourism. Annals of Tourism Research, 38(4), 1344-1366. DOI: 10.1016/j.annals.2011.03.006.

[40] OECD (Organisation for Economic Co-operation and Development) 2002: Glossary (http://stats.oecd.org/glossary/index.htm (05.05.2010)).

[41] OECD (Organisation for Economic Co-operation and Development) (2006): The New Rural Paradigm. Policies and Governance. OECD Rural Policy Reviews. OECD publishing.

[42] Oppermann, M. (1996). Rural tourism in southern Germany. Annals of Tourism Research, 3(1), 86-102. DOI: 10.1016/0160-7383(95)00021-6.

[43] Pike, A., Rodriguez-Pose, A. \& Tomaney, J. (2007). What Kind of Local and Regional Development and for Whom. Regional Studies, 41(9), 1253-1269. DOI: $10.1080 / 00343400701543355$.

[44] Pollermann, K. (2004). Planungsstrategien zur Umsetzung von integrierten Umweltschutzkonzepten für die Landnutzung durch Tourismus, Landwirtschaft und Naturschutz. Beiträge zur räumlichen Planung 77. Hanover: Leibnitz Universität.

[45] Pollermann, K. (2013). Destination Governance aus empirischer Sicht. Analyse von tourismusbezogenen Governance-Arrangements und Schlussfolgerungen für die Praxis. In: Wöhler, K. \& Saretzki, A., Eds., Governance für Destinationen (pp. 131-157). Berlin: Schmidt Erich Verlag.

[46] Pollermann, K., Raue, P. \& Schnaut, G. (2013). Rural development experiences in Germany: opportunities and obstacles in fostering smart places through LEADER. Studies in agricultural economics 115, 111-117. DOI: 10.7896/j.1228.

[47] Randelli, F., Romei, P. \& Tortora, M. (2014). An evolutionary approach to the study of rural tourism: The case of Tuscany. Land Use Policy, 38, 276-281. DOI: 10.1016/j.landusepol.2013.11.009.

[48] Ray, C. (2006). Neo-endogeneous rural development in the EU. In Cloke, P., Marsden, T. \& Mooney, P., Eds. Handbook of rural Studies (pp. 278-291). London: Sage Publications.

[49] Romeiß-Stracke, F. (1989). Neues Denken im Tourismus - Ein tourismuspolitisches Konzept für Fremdenverkehrsgemeinden. München: ADAC-Zentrale.

[50] Saarinen, J. (2006). Traditions of sustainability in tourism studies. Annals of Tourism Research, 33(4), 1121-1140. DOI: 10.1016/j.annals.2006.06.007.

[51] Saxena, A. \& Ilbery, B. (2010). Developing integrated rural tourism: Actor practices in the English/Welsh border. Journal of Rural Studies, 26(3), 260-271. DOI: 10.1016/j.jrurstud.2009.12.001.

[52] Sharpley, R. \& Roberts, L. (2004). Editorial. Rural Tourism - 10 years on. International Journal of Tourism Research 6(3), 119-124. DOI: 10.1002/jtr.478.

[53] Sharpley, R. (2002). Rural tourism and the challenge of tourism diversification: the case of Cyprus. Tourism management, 23(3), 233-244. DOI: 10.1016/S0261-5177(01)00078-4.

[54] Sidali, K. L., Kastenholz, E. \& Bianchi, R. (2013). Food tourism, niche markets and products in rural tourism: combining the intimacy model and the experience economy as a rural development strategy. Journal of Sustainable Tourism, (early bird). DOI: 10.1080/09669582.2013.836210. 
[55] Stronza, A. (2001). Anthropology of tourism: Forging new ground for ecotourism and other alternatives. Annual Review of Anthropology. 30, 261-283. DOI: 10.1146/annurev.anthro.30.1.261.

[56] Terluin, I. (2003). Differences in economic development in rural regions of advanced countries: an overview and critical analysis of theories. Journal of Rural Studies, 19(3), 327-344. DOI: 10.1016/S0743-0167(02)00071-2.

[57] Tourism Sustainability Group (TSG) (2007). Action for more sustainable European tourism. http://ec.europa.eu/enterprise/sectors/tourism/files/docs/tsg/tsg_final_report_en.pdf (27.01.2011).

[58] Volgger, M. \& Pechlaner, H. (2014). Requirements for destination management organizations in destination governance: Understanding DMO success. Tourism Management, 41, 64-75. DOI: 10.1016/j.tourman.2013.09.001.

[59] Wallace, G. \& Russel, A. (2004). Eco-cultural tourism as means for the sustainable development of culturally marginal and environmentally sensitive regions. Tourist Studies, 4(3), 235-254. DOI: 10.1177/1468797604057326.

[60] Ward, N. \& Brown, D. (2009). Placing the Rural in the Regional Development. Regional Studies, 43(10), 1237-1244. DOI: 10.1080/00343400903234696.

[61] Webster, C. \& Ivanov, S. (2014). Transforming competitiveness into economic benefits: Does tourism stimulate economic growth in more competitive destinations? Tourism Management, 40, 137-140. DOI: 10.1016/j.tourman.2013.06.003.

[62] Wilson, S., Fesenmaier, R., Fesenmaier, J. \& Es, J. van (2001). Factors for success in rural tourism development. Journal of Travel Research 132-138. DOI: $10.1177 / 004728750104000203$. 